\title{
REVIEW
}

\section{Aeromonas salmonicida: updates on an old acquaintance}

\author{
Simon Menanteau-Ledouble, Gokhlesh Kumar, Mona Saleh, Mansour El-Matbouli* \\ Clinical Division of Fish Medicine, Department for Farm Animals and Veterinary Public Health, \\ University of Veterinary Medicine, Vienna, Austria
}

\begin{abstract}
Aeromonas salmonicida is the oldest known infectious agent to be linked to fish disease and constitutes a major bacterial pathogen of fish, in particular of salmonids. This bacterium can be found almost worldwide in both marine and freshwater environments and has been divided into several sub-species. In this review, we present the most recent developments concerning our understanding of this pathogen, including how the characterization of new isolates from non-salmonid hosts suggests a more nuanced picture of the importance of the so-called 'atypical isolates'. We also describe the clinical presentation regarding the infection across several fish species and discuss what is known about the virulence of A. salmonicida and, in particular, the role that the type 3 secretion system might play in suppressing the immune response of its hosts. Finally, isolates have displayed varied levels of antibiotic resistance. Hence, we review a number of solutions that have been developed both to prevent outbreaks and to treat them once they occur, including the application of pre- and probiotic supplements.
\end{abstract}

KEY WORDS: Furunculosis · Atypical isolates $\cdot$ Clinical signs $\cdot$ Diagnosis $\cdot$ Probiotics $\cdot$ Virulence mechanisms

\section{INTRODUCTION}

Aeromonas salmonicida is the oldest known fish pathogen and is currently endemic almost worldwide in both fresh and marine waters (Hiney \& Olivier 1999). While it is best known as a pathogen of salmonid fish, multiple other species can be infected (Wiklund \& Dalsgaard 1998). In particular, the development of aquaculture to new species has led to the increased isolation of new strains of the bacterium belonging to so-called 'atypical' species. Many such isolates appear to show a pattern of homology that correlates with their host of origin. This suggests that the dichotomy between 'typical' and 'atypical' isolates of the bacterium is likely an over-simplification and is caused by the dominance of salmonid species in aquaculture.
Varied clinical signs are associated with the infection in different fish species, although skin ulcerations and haemorrhages are recurrent features. Among the virulence factors that cause these clinical signs, the type 3 secretion system (T3SS) has received the most recent attention. Multiple effector proteins have been identified and their putative effects described, often based on homology. One particularly interesting function of the T3SS is to interfere with immune signalling inside the host and repress the inflammatory response (Vanden Bergh \& Frey 2014).

Several approaches have been adopted to control this disease. A bacterin vaccine has proven efficacious in salmonids but is associated with side effects (Midtlyng 1997a, Koppang et al. 2005, Villumsen et al. 2015). Furthermore, its efficacy is still unclear

() The authors 2016. Open Access under Creative Commons by Attribution Licence. Use, distribution and reproduction are unrestricted. Authors and original publication must be credited. 
when applied to non-salmonid species (Björnsdóttir et al. 2005). This and the development of antibiotic resistance have fuelled the need for alternative methods of disease management, including through the use of feed supplement with probiotics, prebiotics and immunostimulants. Furthermore, selective breeding has been applied to control infections by $A$. salmonicida in several countries (Cipriano et al. 2002, Ødegård et al. 2007). Strains of salmonids have been developed that are considered resistant to infections (Cipriano et al. 2002). Here we review these recent additions to our understanding of this pathogen and aim to provide an updated overview of A. salmonicida infections.

\section{PHYLOGENY AND CLASSIFICATION}

\section{Within the genus}

The phylogeny of aeromonads has long been the subject of debate. One of the reasons why the subject is yet to be settled is the high level of genetic similarity between most species within this genus (Hänninen \& Hirvelä-Koski 1997); however, more sensitive identification methods will detect differences that are beyond the notice of less sensitive techniques (Martínez-Murcia et al. 1992). For example, a study by Martínez-Murcia et al. (2005) suggested that DNA-DNA hybridization methods are not sensitive enough to discriminate between highly similar aeromonad species. Similarly, analyses of $16 \mathrm{~S}$ rDNA by restriction fragment length polymorphism and sequencing have been inconclusive: the 16S rRNA sequences from the type strains from typical Aeromonas salmonicida and $A$. bestiarum only diverged by 2 nucleotides, and the sequences of several isolates belonging to these strains were ambiguous (Martínez-Murcia et al. 1992), displaying a double sequencing signal at these positions (MartínezMurcia et al. 2005). Conversely, sequencing of the housekeeping genes $r p o D$ and $g y r B$, which constitute faster molecular chronometers, led to a clear clustering of the isolates within 4 distinct groups and allowed a clear discrimination between A. salmonicida and A. bestiarum (Martínez-Murcia et al. 2005).

The current consensus seems to be that $A$. salmonicida and $A$. bestiarum are distinct species. A. salmonicida is then divided between $A$. salmonicida subsp. salmonicida, the typical $A$. salmonicida and 'atypical' isolates that do not match the fairly narrow and homogenous description of typical isolates (Austin et al. 1998).

\section{Within the A. salmonicida species}

Discriminating between the various isolates remains a vexing problem: 'typical' $A$. salmonicida subsp. salmonicida was the first sub-species described and has received by far the most scrutiny. In addition, 4 sub-species of 'atypical' $A$. salmonicida are generally recognized: A. salmonicida subsp. achromogenes; A. salmonicida subsp. masoucida; A. salmonicida subsp. smithia; and A. salmonicida subsp. pectinolytica (Pavan et al. 2000, Gudmundsdóttir et al. 2003). However, new atypical isolates have been reported that do not fit well within any of the known species or sub-species (Gudmundsdóttir 1998, Wiklund \& Dalsgaard 1998), and Cipriano \& Austin (2011) questioned the validity of this classification scheme.

A. salmonicida subsp. salmonicida has long been described as very homogeneous from a biochemical and physical standpoint. For example, when characterizing the bacterium using 14 different biochemical tests on 71 isolates of A. salmonicida subsp. salmonicida, Hirvelä-Koski et al. (1994) obtained unambiguous results (with either all or none of the tested isolates positive) for 12 parameters. This homology holds true at the genomic level; for example, a $512 \mathrm{bp}$ sequence belonging to an, at the time, unknown gene (now, annotated as including a segment from both a hypothetical protein and a transcriptional regulator belonging to the XRE family) was more than $99 \%$ similar among 54 isolates (Diamanka et al. 2013). Similarly, random amplified polymorphic DNA analysis (RAPD) was performed by Miyata et al. (1995) and produced identical profiles for all 13 isolates of $A$. salmonicida tested. Comparable results were obtained by O'hIci et al. (2000) when they applied RAPD to 20 isolates of $A$. salmonicida subsp. salmonicida. Moreover, in the same study, the authors applied pulse field gel electrophoresis (PFGE) following genomic digestion with the endonucleases $X b a I$ and SpeI and, once again, obtained very similar results for all isolates of $A$. salmonicida subsp. salmonicida (O'hIci et al. 2000). Ribotyping was also unable to discriminate among 124 isolates of $A$. salmonicida subsp. salmonicida because of the high level of homology within this sub-species (Nielsen et al. 1994). Another approach by the same authors was to compare the plasmid profiles. While there was more heterogeneity regarding this mobile genetic element, once again, no clear patterns were visible between isolates, leading the authors to conclude that plasmid profiles were of limited use for epidemiological applications (Nielsen et al. 1993). More 
recently, DNA microarray was applied in combination with comparative genomic hybridization. Nash et al. (2006) investigated 2024 genes belonging to 11 isolates of A. salmonicida subsp. salmonicida alongside 11 atypical isolates. Their analysis revealed that the typical isolates were homologous and confined within a distinct cluster.

In contrast with the sub-species of A. salmonicida, 'atypical' isolates are reported to present a higher level of heterogeneity (Lund et al. 2002). However, Beaz-Hidalgo \& Figueras (2012) considered it very difficult to discriminate between sub-species. Martínez-Murcia et al. (2005) reached a similar conclusion, although they suggested that sequencing of the $g y r B$ and $r p o D$ genes might prove a useful tool for the comparison of isolates of $A$. salmonicida. Nonetheless, results from PFGE were compared between A. salmonicida subsp. salmonicida and A. salmonicida subsp. achromogenes and clearly separated the 2 sub-species (Livesley et al. 1999). Similarly, both repetitive extragenic palindromic PCR and endobacterial repetitive intergenic consensus PCR (ERICPCR) have been applied to $A$. salmonicida (BeazHidalgo et al. 2008). ERIC-PCR was able to specifically identify $A$. salmonicida subsp. salmonicida but was not able to discriminate between A. salmonicida subsp. masoucida and 1 A. salmonicida subsp. achromogenes (Beaz-Hidalgo et al. 2008).

Recently, matrix-assisted laser desorption/ionization-time-of-flight mass spectrometry (MALDI-TOF MS) has been applied to the analysis of A. salmonicida. For example, Wang et al. (2007) analysed the lipopolysaccharide composition of multiple A. salmonicida isolates; they were able to define 3 groups and found some correlation between this grouping and host-species from which the isolates originated. Moreover, Benagli et al. (2012) successfully discriminated between members of the Aeromonas genus at the genospecies level, using proteomic fingerprinting. However, the authors reported difficulties with identifying the isolates at the sub-species level (Benagli et al. 2012). Akyar \& Can (2013) reported better success, but their study included many varied strains of aeromonads, only 2 of which were $A$. salmonicida. Jansson et al. (2015), on the other hand, analysed 11 isolates of $A$. salmonicida and similarly reported difficulties with identifying isolates at the sub-species level. However, these authors also reported that most of the misidentifications were due to errors in the database (Jansson et al. 2015). Similarly, Lamy et al. (2011) also attributed their difficulties in identifying the bacterium at the sub-species level to inaccuracies in the database. It therefore seems plausible that, as the use of MALDI-TOF develops and our databases expand, this technique will gain in precision.

Interestingly, when investigating 43 isolates from goldfish Carassius auratus, Shotts et al. (1980) found them to form a homogeneous group, distinct from the typical isolates. Similarly, Lund et al. (2002) reported that the profiles of 56 atypical isolates correlated with the host species from which they were originally isolated when subjected to amplified fragment length polymorphism (AFLP) fingerprinting. Whittington et al. (1995) obtained more ambiguous results by applying restriction endonuclease fragment patterns (REFP) on isolates from goldfish, perch and flounder. While flounder isolates displayed a similar and distinct pattern, those from goldfish and perch were indistinguishable (Whittington et al. 1995). Moreover, since the introduction of these fish species as a means of biocontrol, new isolates of atypical $A$. salmonicida have been sampled from diseased lumpfish Cyclopterus lumpus and Ballan wrasse Labrus bergylta. These new isolates appear distinct, once again suggesting a correlation between the host of origin and the isolates' profile (Gulla et al. 2015a, Rønneseth et al. 2015). Similarly, isolates originating from turbot Scophthalmus maximus appears more virulent to this species than isolates from salmonids or from the environment (Lago et al. 2012), and a report by Diamanka et al. (2014) suggested that the isolates of atypical $A$. salmonicida affecting sea lampreys Petromyzon marinus in the North American Great Lakes were highly unusual and might even constitute a new sub-species.

Many authors have commented in the past on how homologous typical isolates of $A$. salmonicida were. Indeed, the use of the term 'typical' $A$. salmonicida tends to suggest that this sub-species is the 'normal' form of the bacterium and that other isolates merely represent deviations from this norm. However, this view is likely influenced by the dominance of salmonids in cold-water aquaculture. In recent decades, as cold-water aquaculture has developed toward the farming of new species, and new isolates are being recovered from these species, a pattern seems to be emerging whereby, rather to be one-off examples, atypical isolates actually belong to homogeneous clusters that tend to preferentially target specific host species or a small group of species. In this regard, each of these clusters would be 'typical' for this particular niche. Indeed, different sub-species can express different virulence factors, and these might contribute to the specialization of some groups of $A$. salmonicida (Gudmundsdóttir 1996). The current 
classification only partially predicts the host species from which the isolates originated, and its validity has been questioned (Cipriano \& Austin 2011).

\section{CLINICAL SIGNS}

\section{Salmonids}

In salmonids, 3 forms of the disease have routinely been described: peracute, acute and chronic; in addition, cover infections, in which asymptomatic carriers act as a source of infection, are known to occur.

The peracute form of the disease is mostly found in younger fish and is accompanied with very few clinical signs. Darkening of the skin can sometimes be observed, as are exophthalmia and a distended abdomen (Hiney \& Olivier 1999, Cipriano \& Austin 2011). Histological examination might reveal damage to the heart tissue (Roberts 2012), focal necrosis on the gills and destruction of the spleen ellipsoids (Bernoth 1997).

In the acute form, the same clinical signs can be observed, in addition to anorexia. Petechia and haemorrhages can be observed both externally, especially at the base of the fins and on the internal organs (Fig. 1) (Hiney \& Olivier 1999, Cipriano \& Austin 2011). In addition, the spleen is often enlarged (Bernoth 1997) (Fig. 2). Histopathologically, the observations are similar to those from the peracute stage, and may also involve necrosis of the interstitial tissue in the kidney (Fig. 3), and the ellipsoids in the spleen are often infiltrated by a large number of macrophages (Cipriano \& Austin 2011).

In the chronic forms of the disease, haemorrhages alongside the digestive tract have been reported, and it is in this form of the disease that the pathognomonic furuncal lesions are the most likely to be encountered (Cipriano \& Austin 2011, Roberts

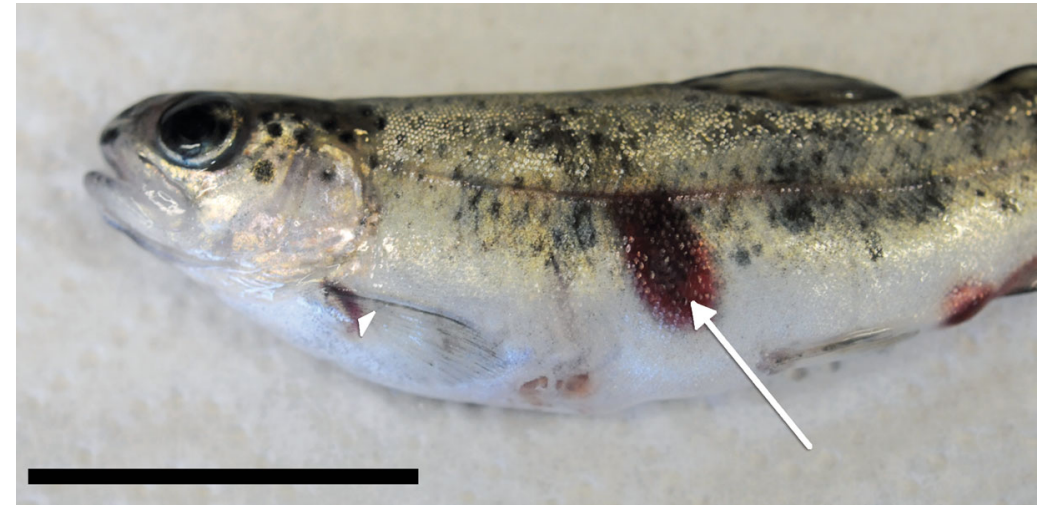

Fig. 1. External appearance of a rainbow trout Oncorhynchus mykiss after intra-peritoneal injection with Aeromonas salmonicida subsp. salmonicida. Particularly noticeable are the haemorrhagic lesions at the site of injection (arrow), as well as the haemorrhagic lesion at the base of the fin (arrowhead) and the protruding, bloody anal vent. Scale bar $=2.5 \mathrm{~cm}$

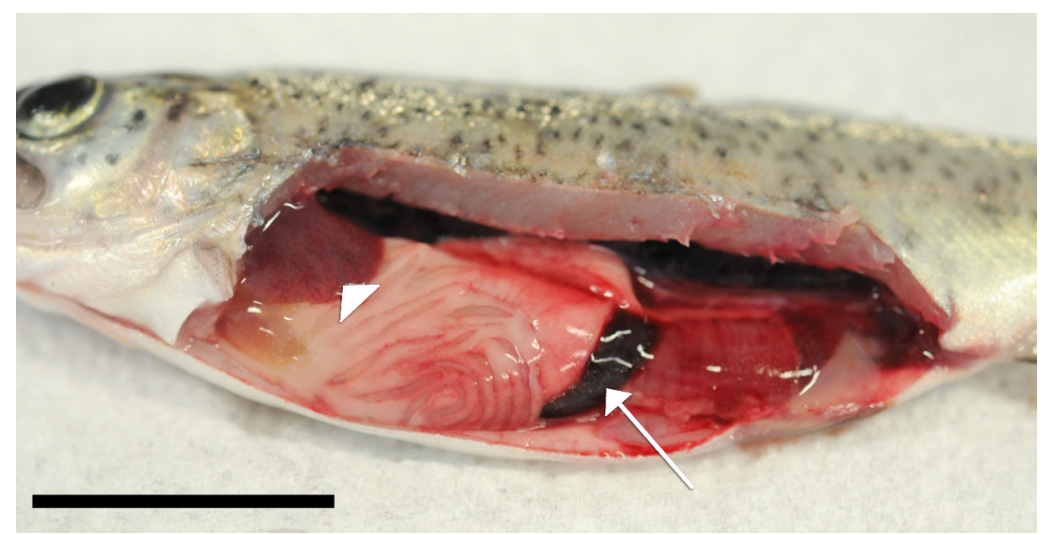

Fig. 2. Appearance of the internal organs from a rainbow trout Oncorhynchus mykiss following infection with Aeromonas salmonicida subsp. salmonicida. In addition to the widespread systemic haemorrhages visible through the organs, striking features include the enlarged spleen (arrow) and the liver punctuated with foci of petechial haemorrhages (arrowhead). Scale bar $=2.5 \mathrm{~cm}$
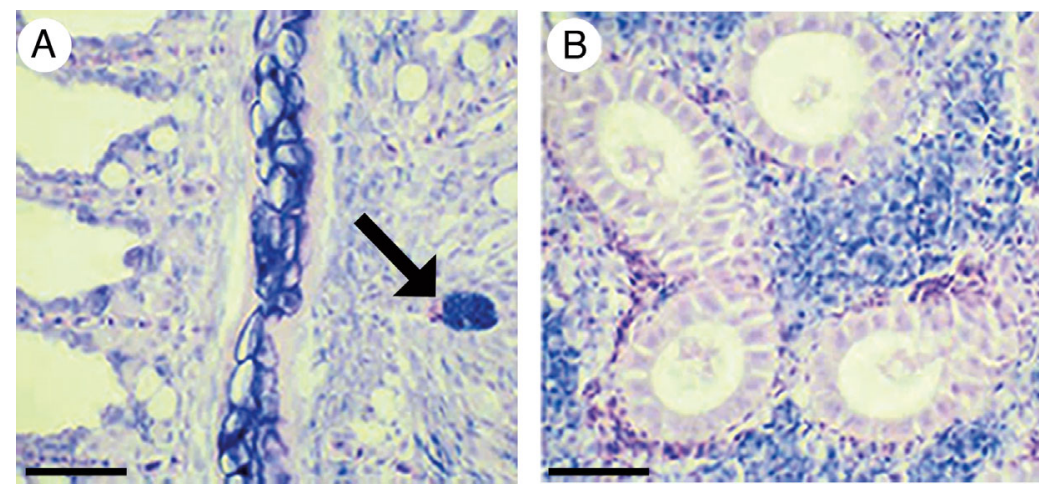

Fig. 3. Histopathological appearances of the gills and kidney from turbot Scophthalmus maximus after intra-muscular injection with Aeromonas salmonicida subsp. achromogenes. (A) Gills showing a bacterial colony located in the blood vessel in fused secondary lamellae (arrow). (B) Kidney displaying areas of haemorrhages surrounding the tubules. Scale bars $=100 \mu \mathrm{m}$. Reproduced from Björnsdóttir et al. (2005) (their Fig. 1c,d), with permission 
2012). In some cases, the bacteria appear restricted to the digestive system. In this case, infections can induce low mortalities and is marked by a prolapsed anus (Bernoth 1997).

\section{Cyprinids}

In cyprinids, Aeromonas salmonicida infection mostly appears as an external disease with whitish nodules. These can develop under the scales and become inflamed, degenerating into an area of haemorrhage on the epithelium. If the infection progresses, the scales can be lost and the site becomes an ulcerative lesion (Jeney \& Jeney 1995, Cipriano \& Bullock 2001). At the histopathological level, the lesions appear granulomatous with infiltration of a large number of inflammatory cells (Jeney \& Jeney 1995).

In goldfish, the infection starts with white proliferations on the epithelium. Haemorrhages can appear under the scales and develop into an ulcerative lesion. Afterwards, the scales are sloughed off and the dermis and subjacent musculature can become necrotic (Cipriano \& Bullock 2001).

A. salmonicida infections in cyprinid fish have sometime been termed 'carp erythrodermatitis' and 'ulcer disease', emphasizing the importance of this cutaneous presentation (Shotts et al. 1980, Cipriano \& Bullock 2001, Kodama et al. 2011). In the most serious cases, the fish can show signs of systemic disease, displaying exophthalmia and a distended abdomen (Cipriano \& Bullock 2001).

\section{Walking catfish}

Thomas et al. (2013) reported on the clinical signs following infection of the walking catfish Clarias batrachus with A. salmonicida delivered through different routes (feeding with infected meat, immersion in a bacterial solution and intraperitoneal injection). These authors reported a loss of mucus cells and mucus gland in the skin as well as severe damage and destruction of the secondary lamellae in the gills alongside irregular vacuolation in the liver.

\section{Eels}

In both American eel Anguilla rostrata and Japanese eel $A$. japonica, the disease is charac- terized by small discoloured patches on the skin. These can progress into deep ulcers of 5 to $30 \mathrm{~mm}$ in diameter. These ulcerations often involve the underlying muscle tissue, and gill lesions have been reported (Noga \& Berkhoff 1990). Histopathologically, these lesions were marked with oedema and the appearance of necrosis and a developing inflammatory response alongside isolated bacteria or bacterial microcolonies (Noga \& Berkhoff 1990).

\section{Cod}

In cod Gadus morhua, petechia and haemorrhages can be observed on the skin, in particular in the oral area and on the ventral side, along the flanks and near the anus (Magnadóttir et al. 2002). In some cases, these lesions can develop into ulcers (Cornick et al. 1984). Haemorrhages can also be observed in the gills that often appear pale and anaemic. Internally, the liver can appear moulted, and disseminated haemorrhages are present alongside the digestive track, particularly in the lower intestine (Magnadóttir et al. 2002). At the histopathological level, the most marking feature of the disease is the granulomatous formation with infiltration of monocytes and lymphocytes, reminiscent of what has been described in cyprinids (Samuelsen et al. 2006). However, these lesions are not only visible around the ulcers but also disseminated throughout most internal organs with the exclusion of the brain and gonads (Magnadóttir et al. 2002) (Fig. 4).

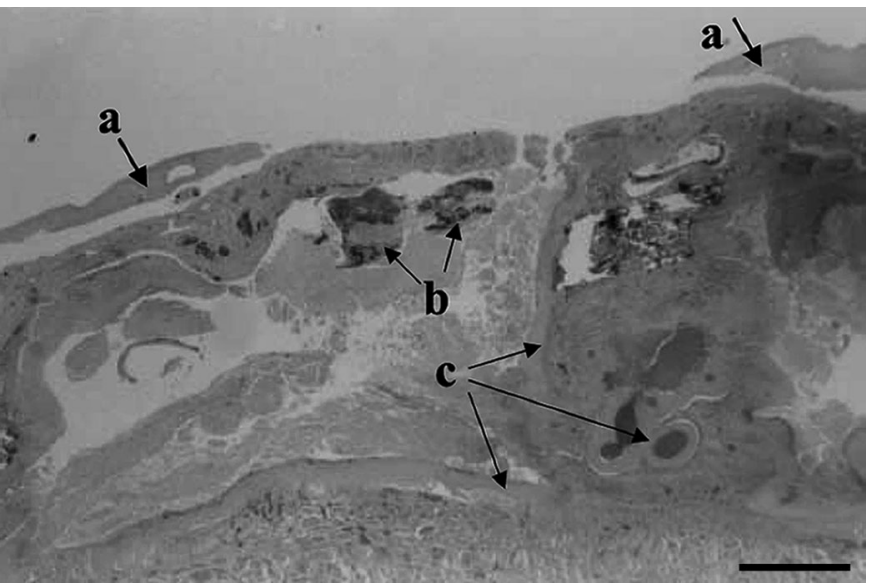

Fig. 4. Histopathological appearance of an ulcerative lesion on the skin of a naturally infected cod, Gadus morhua. Important features of the lesion include (a) the edges of the lesion; (b) areas where the bacteria are mixed with necrotic cells and (c) areas of granulomatous inflammation. Scale bar $=100 \mu \mathrm{m}$. Reproduced from Magnadóttir et al. (2002) (their Fig. 1), with permission 


\section{Turbot}

Skin lesions have also been associated with $A$. salmonicida infections in turbot. Ulcers developed at the site of infection within $7 \mathrm{~d}$ of infection with $A$. salmonicida subsp. achromogenes (Björnsdóttir et al. 2005). Inflammation and haemorrhages were observed surrounding the sites of injection and at the fin base and in the mouth area. The gills were pale, suggesting a lack of blood in this organ. Internally, the fish developed ascites alongside darkening of the peritoneal wall (Björnsdóttir et al. 2005). At the histopathological level, haemorrhages and liquefactive necrosis were observed in the muscle tissues. The gills displayed hyperplasia and hypertrophy with fusion of the secondary lamellae. Haemorrhages and limited necrosis were observed in the kidney, and tissue degeneration was visible in the heart (Björnsdóttir et al. 2005). The gut was left undamaged. As in other species, a strong immune response was observed with infiltration of macrophages and monocytes. More recently, similar signs were observed in naturally infected turbot (Coscelli et al. 2014b). In addition, skin nodules of 2 to $6 \mathrm{~mm}$ were observed on the head and operculum. These nodules could progress into ulcers, and histological examination revealed the presence of dermal chronic granulomatous inflammation. In a different study, abnormal swimming and anorexia were reported as well as haemorrhagic lesions on the liver (Farto et al. 2011). In that case, the bacteria could be reisolated from the mucus of the skin, gills and intestine, suggesting a possible route for the dispersion of the bacterium in the environment (Farto et al. 2011). Interestingly, a different outcome was obtained during another artificial infection where the bacteria were injected intra-peritoneally (Coscelli et al. 2014a). The authors reported that gross lesions were not significantly observed in the fish. Moreover, perhaps unsurprisingly, the coelomic cavity appeared as the first and most severely infected site. Perivascular oedema was observed in kidneys, and mild haemorrhage was observed in the parenchyma of the liver and spleen. Foci of necrosis surrounded bacterial colonies in the infected organs, including the kidney, liver, spleen and pancreas, and mild necrosis was detected in gills, thymus and gonads. Also in contrast to Björnsdóttir et al. (2005) and their own previous study, the authors reported that no leukocyte infiltrates were observed in association with the bacterial colonies (Coscelli et al. $2014 b)$. The reason for the discrepancies between the 2 studies is unknown. The infectious dose used by Coscelli et al. (2014a), viz. $100 \mu \mathrm{l}$ of bacterial solution totalling $10^{8} \mathrm{CFU}$ fish $^{-1}$, was identical to the highest dose tested by Björnsdóttir et al. (2005), suggesting that the differences might have to do with the route of infection used or differences in the bacterial isolate or the fish tested.

\section{Wrasse and lumpfish}

Ballan wrasse and lumpfish are increasingly being used as 'cleaner fish' in the biocontrol of ectoparasites (salmon lice Lepeophtheirus salmonis) in the salmon industry (Treasurer 2012). However, A. salmonicida, in particular atypical isolates, are commonly diagnosed from these species (Collins et al. 1991, Gulla et al. 2015a,b). In wrasse, bacteria have been isolated from the gills and internal organs (Collins et al. 1991). Presence of bacterial microcolonies and the development of granulomas surrounding a necrotic anterior have been reported (Vågnes et al. 2014). Conversely, Treasurer (2012) reported the occurrence of mortalities as high as $19 \%$ even in the absence of clinical signs.

The situation in these species is unique because they are by design cultivated in close proximity with salmonids. Furthermore, the sea lice on which cleaner fish are feeding have been shown to harbour the bacterium (Nese \& Enger 1993, Novak 2013). Therefore, it is likely that during some of the outbreaks, the contamination was transmitted from the salmon to the cleaner fish (Treasurer 2012).

\section{Common and spotted wolffish}

Common wolffish Anarhichas lupus and spotted wolffish A. minor are emerging species for aquaculture in the northern Atlantic (Hellberg et al. 1996, Falk-Petersen et al. 1999, Foss et al. 2004). Outbreaks of disease due to atypical A. salmonicida have been reported in both species (Hellberg et al. 1996, Foss et al. 2004). In the common wolffish, the mortalities occurred in the warmest months and were associated with ulcers of 1 to $2 \mathrm{~cm}$ in diameter on the sides and the edges of the tail (Hellberg et al. 1996, Rodger et al. 1997), alongside fin erosion (Rodger et al. 1997). Petechial haemorrhages were reported on the intestine, and hyperaemia in the surrounding tissue (Hellberg et al. 1996). Foci of necrosis and bacterial accumulation were also visible in the liver (Rodger et al. 1997) and haematopoietic tissues (Hellberg et al. 1996). 


\section{Atlantic halibut}

Atlantic halibut Hippoglossus hippoglossus subjected to infection trials using both typical and atypical isolates of $A$. salmonicida were not very susceptible to the disease (Hjeltnes et al. 1995, Bricknell et al. 1999). Immersion baths failed to establish infections using both typical and atypical isolates, and, when injecting the bacteria intraperitoneally, only the highest doses of the bacterium $\left(10^{6}\right.$ to $10^{8} \mathrm{CFU}$ ind. $\left.{ }^{-1}\right)$ resulted in mortalities (Bricknell et al. 1999). The likelihood of these fish acting as vectors of infection appears similarly limited, as Hjeltnes et al. (1995) could not re-isolate the bacteria from infected fish. Similarly, Bricknell et al. (1999) were only able to reisolate the bacteria from 2 out of 87 of the halibut injected with the bacterium, and only from the digestive tract. Because the halibut were co-habitating with infected salmon, the authors suggested that this might only reflect a transient presence of the bacteria through the intestine rather than an active colonization (Bricknell et al. 1999).

In the halibut that displayed clinical signs, lethargy and darkening in colour as well as congestion of the blood vessels at the base of the fins were reported (Bricknell et al. 1999). Internally, the viscera were haemorrhagic and the liver was pale, and at the histopathological level, liquefactive necrosis was reported from multiple tissues (Bricknell et al. 1999); the spleen in particular was congested and presented foci of necrosis, while bacterial microcolonies were observed in the myocardium (Bricknell et al. 1999).

\section{Other marine species}

Ulcerative lesions and haemorrhages have been described on the body surface, especially in the mouth area and the operculum, of infected black rockfish Sebastes schlegeli following a natural outbreak. The eyes and intestines also showed signs of haemorrhages, and the spleen and kidney were sometimes swollen in appearance (Han et al. 2011).

In sea lamprey Petromyzon marinus, Faisal et al. (2007) similarly reported localized swellings on the dorsal fin and muscle as well as shallow ulcerations and furuncle-like lesions.

The first report of an outbreak of A. salmonicida in haddock Melanogrammus aeglefinus was due to $A$. salmonicida subsp. achromogenes (Treasurer et al. 2007). The clinical signs of the disease included haemorrhages on the fins and gills as well as a bloody exudate from the vent. Bacterial micro- colonies surrounded the gill lesions, and a significant immune response was reported (Treasurer et al. 2007). Diffuse haemorrhages were also observed on the liver alongside multifocal hyperplasia of the histiocytes in the endocardium alongside hydroptic degeneration of the tubular cells in the kidney. Finally, multifocal liquefactive necrosis and bacterial microcolonies were reported from the haematopoietic tissues in the spleen and kidneys (Treasurer et al. 2007).

It is also worth mentioning that, based on these descriptions, the term 'furunculosis' often used to describe the disease seems somewhat misleading, as the pathognomonic furuncles only develop in a small number of the fish infected by the disease.

\section{DIAGNOSIS}

Isolation of Aeromonas salmonicida is traditionally accomplished by cultivation, frequently on tryptic soy agar or blood agar, where 'typical' isolates produce a characteristic brown, diffusible pigment in culture, as shown in Fig. 5 (Cipriano \& Austin 2011). A. salmonicida is then distinguished from other fish pathogens on the basis of a variety of phenotypic tests, particularly the Gram-staining reaction (short Gram-negative rods) and, for most isolates, lack of motility (Austin \& Austin 2012). However, the reliability of these tests alone as a diagnostic tool has been called into question (Beaz-Hidalgo \& Figueras 2012).

Several methods have also been designed for the diagnosis of this bacterium (Hiney \& Olivier 1999).

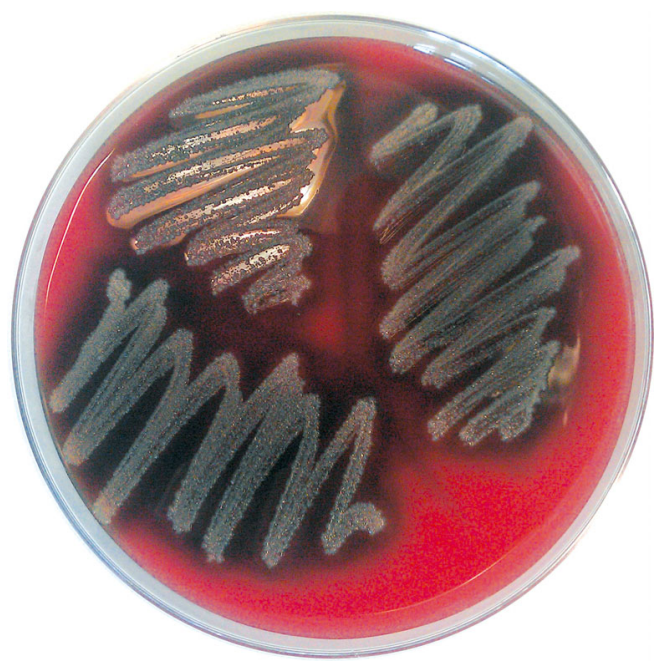

Fig. 5. Appearance of Aeromonas salmonicida subsp. salmonicida cultivated on blood agar plate and secreting the characteristic brown diffusible pigment 
Most recently, polyclonal antibody-coated gold nanoparticles were applied in an immunoassay (Saleh et al. 2011) and enabled the detection of $A$. salmonicida $\left(1 \times 10^{4} \mathrm{CFU} \mathrm{ml}{ }^{-1}\right)$ within $45 \mathrm{~min}$ (Fig. 6).

Similarly, a host of molecular tools have been applied and optimized for the detection of Aeromonaceae. These were reviewed by Beaz-Hidalgo \& Figueras (2012); however, since the publication of that review, a reverse transcription-multiplex PCR (RT-MPCR) method was developed that allowed the detection of as few as $30 \mathrm{CFU}$ of the bacterium and had the added advantage of discriminating between live and non-viable bacterial cells (Rattanachaikunsopon \& Phumkhachorn 2012). Furthermore, a new protocol was described by Keeling et al. (2013) that targeted the surface array protein (vapA) gene of $A$. salmonicida. This method was further optimized by Gulla et al. (2015a) for isolates originating from wrasses, a group of fish that are increasingly being employed as cleaner fish for the control of salmon lice.

Finally, MALDI-TOF has also been used to identify isolates of A. salmonicida (Lamy et al. 2011, Benagli et al. 2012, Jansson et al. 2015) and, as the databases used for the identification improve, might also allow discriminating between the various sub-species of $A$. salmonicida.

\section{VIRULENCE MECHANISMS}

As is the case for many bacterial pathogens, the expression of virulence factors in Aeromonas salmonicida is tightly regulated. For example, A. salmonicida subsp. salmonicida can secrete no less than 4 distinct types of acylated homoserine lactones, of which $N$-butanoyl-L-homoserine lactone (C4-HSL) is the most important (Schwenteit et al. 2011). Quorum sensing has been linked to the secretion of protease in the bacterial supernatant (Swift et al. 1997, Rasch et al. 2007). Similarly, iron availability influenced the expression of superoxide dismutase, and A. salmonicida grown under iron-limited conditions started producing a second, larger, superoxide molecule (Barnes et al. 1996). Iron deprivation also increased the transcription levels of the enzyme enolase, found to be both secreted and present in the outer-membrane fraction of the bacterium (Vanden Bergh et al. 2013, Menanteau-Ledouble et al. 2014a). Enolase is over-expressed during the infectious process in $A$. hydrophila (Sha et al. 2003) and participates in the binding to plasminogen. Application of in vivo induced antigen technology (IVIAT) to A. salmonicida

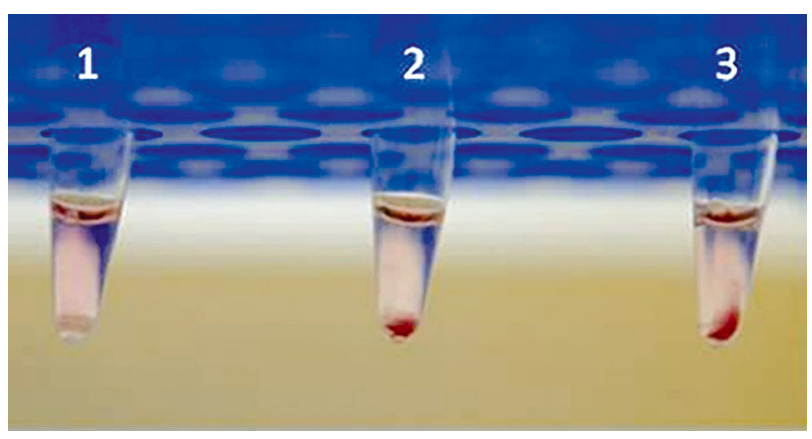

Fig. 6. Antibody-coated gold nanoparticle immunoassay allowing for the quick detection of Aeromonas salmonicida. Tube 1: Negative control; Tube 2: Atypical Aeromonas salmonicida; Tube 3: Aeromonas salmonicida subsp. salmonicida. Notice the reddish purple agglutination in the last 2 tubes, characteristic of a positive result. Reproduced from Saleh et al. (2011) (their Fig. 2), with permission

also revealed that $\operatorname{ton} B$ was significantly expressed in vivo (Menanteau-Ledouble et al. 2014b), illustrating the central role of iron acquisition in the disease process.

A number of virulence factors have been characterized, and several excellent reviews have been recently published on this subject. For example, BeazHidalgo \& Figueras (2013) reviewed several virulence factors encoded on the genome of members of the genus Aeromonas with a special emphasis on the evolution of these pathogens. Dallaire-Dufresne et al. (2014) provided an overview of the various mobile genetic elements identified in A. salmonicida, while Vanden Bergh \& Frey (2014) focussed on the T3SS of the bacterium and its various associated effector proteins, offering an in-depth overview of this subject.

Since the publication of these reviews, however, the enzyme lactoylglutathione lyase has been shown to be strongly over-expressed by A. salmonicida during the infectious process (Menanteau-Ledouble \& El-Matbouli 2015). In other bacterial species, this enzyme is involved in the resistance of oxidative and $\mathrm{pH}$ stress and cellular detoxification ( $\mathrm{Li}$ et al. 2003, Korithoski et al. 2007) and is required for intracellular invasiveness and especially the translocation of effector proteins encoded within the second Salmonella pathogenicity island (Chakraborty et al. 2014).

Another virulence mechanism involves the lipopolysaccharides (LPS). These molecules also strongly stimulate the immune response and are considered the most important contributors to endotoxicity in Gram-negative bacteria (Schromm et al. 2000, Anwar \& Choi 2014). LPS can display haemolytic activity against fish erythrocytes (Lee \& Ellis 1991). In A. salmonicida, both smooth LPS and rough LPS (char- 


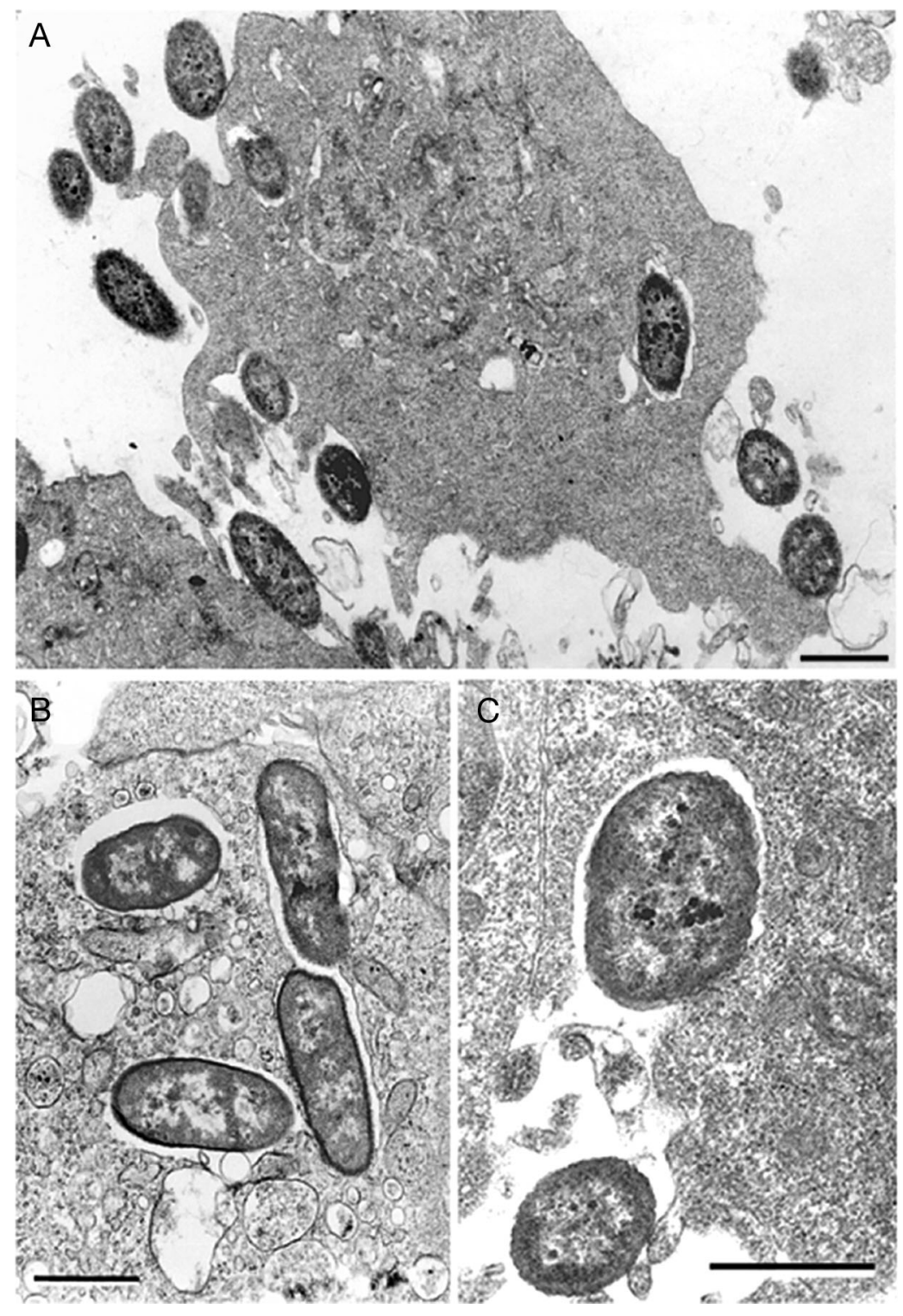

Fig. 7. Aeromonas salmonicida invasion of non-phagocytic cells as observed by transmission electron microscopy. Scale bars $=1.0 \mu \mathrm{m}$. (A) Wild-type $A$. salmonicida in the process of invading an epithelioma papulosum cyprini (EPC) cell; (B) intracellular S-layer-deficient avirulent mutant inside a cell from the Chinook salmon embryo (CHSE) cell line; (C) an avirulent O-polysaccharide-negative, S-layer-secreting $A$. salmonicida in the process of being internalized by an EPC cell. All micrographs were obtained from samples fixed after $1 \mathrm{~h}$ of exposure to the bacteria. Reproduced from Garduño et al. (2000) (their Fig. 3a,b,c), with permission

acterized by missing oligosaccharide and outer core) have been described. In this species, the O-antigen is composed of 3 repeating monosaccharides instead of 1 or 2, as previously known in other bacteria (Merino et al. 2015). The basic structure of lipid A appears relatively well conserved among Aeromonaceae, although differences in acetylation patterns introduce diversity, with the hexaacyl lipid A associated with smooth LPS (Wang et al. 2006, Anwar \& Choi 2014). Studies have suggested that the UDP-3-O-acyl-N-acetylglucosamine deacetylase, a membrane peptidase involved in the second step of the synthesis of lipid A, was present at a higher rate during the infection process than in vitro (MenanteauLedouble et al. 2014b).

The T3SS of A. salmonicida might represent the most important virulence factor in this species (Burret al. 2003, Burr et al. 2005) and has received sustained scrutiny in recent years. Several effector proteins have been described (Vanden Bergh \& Frey 2014) and linked to intracellular survival (Fast et al. 2009) (Fig. 7).

Among these effector proteins is AopO, which is overexpressed by the bacterium during the infectious process (Menanteau-Ledouble \& El-Matbouli 2015) and plays a role in the virulence of the bacterium during immersion challenge (Dacanay et al. 2006). Inactivation of this gene alone did not affect the bacterial virulence when administered intra-peritoneally (Dacanay et al. 2006), which suggests that the protein's main role may be in the initial steps of the infection or that other proteins play a similar role and could compensate for the inactivation of AopO. AopO is homologous to the YopO/YpkA effector proteins of Yersinia (Vanden Bergh \& Frey 2014) that can induce apoptosis through disruption of the actin filaments (Nejedlik et al. 2004) and can inhibit phagocytosis by inhibiting the activation of the Rac proteins (Groves et al. 2010).

The effector proteins might also play a role in reducing the immune response. AopP presents a high analogy with YopJ/P expressed by Yersiniaceae, and this molecule reduces the expression of NF-кB (Fehr et al. 2006, Vanden Bergh \& Frey 2014). Because of the role of NF- $\mathrm{kB}$ as a cytokine regulator (Lawrence 2009), AopP likely allows the bacterium to reduce the immune response, making the host more susceptible to infection. Indeed, constitutive expression of AopP by Drosophila mutants reduced survival following bacterial infection (Jones et al. 2012). 
Similarly, AopN is homologous to effector proteins from other species, for example BopN from Bordetella that is known to induce the immunosuppressive interleukin 10 (Nagamatsu et al. 2009). Another homolog of AopN is CopN of Chlamydia, a molecule that binds to $\alpha \beta$-tubulin and hinders the formation of microtubules, ultimately leading to the cessation of mitosis (Archuleta et al. 2011). Moreover, AopS is an analog of the effector protein VopS characterized in Vibrio parahaemolyticus. VopS causes AMPylation of Rho GTPases and in turn inhibits several immune signalling pathways such as NF- $\kappa$, Erk and JNK kinase (Woolery et al. 2014).

A. salmonicida subsp. salmonicida in salmonids is only associated with limited levels of inflammation and leukocytic infiltrations (Midtlyng 2014), which might be explained by the action of effectors of the T3SS (Vanden Bergh \& Frey 2014). Indeed, Magnadóttir \& Gudmundsdóttir (1992) commented on the limited antibody levels raised by A. salmonicida and suggested that the bacterium might have immunosuppressive effects. Mulder et al. (2007) reported increased transcription levels of several pro-inflammatory genes, but their approach relies on the use of RT-qPCR and, therefore, does not rule out an immunosuppressive effect at the post-transcriptional level, as would most likely occur if an effector of the T3SS were involved. Furthermore, while Rojas et al. (2015) recently reported that Caspase-1, an enzyme involved in processing many such pro-inflammatory cytokines, was activated in the presence of $A$. salmonicida, they relied on UV-inactivated bacteria. Therefore, that study did not rule out an active immunosuppressive action of the bacterium, consistent with the findings of Long et al. (2015), who reported that while several immune factors, most notably interleukine- 8 and interleukine- $1 \beta$, were strongly over-transcribed, these did not translate into an increased production of the corresponding proteins, suggesting that an unknown factor appeared to reduce the expression of these inflammatory proteins at the post-translational level.

\section{CONTROL AND PREVENTION}

\section{Vaccination}

Currently, the fish farming industry has widely adopted a bacterin vaccine, generally administered by intra-peritoneal injections alongside an oil emulsion-based adjuvant (Midtlyng 1997b, 2014). Interestingly, the combination of the vaccine and oil adju- vant has been linked to the non-specific activation of macrophages in the head kidney that have the ability to eliminate Aeromonas salmonicida (Midtlyng 2014). However, delivery of the vaccine by injection is cumbersome when dealing with large numbers of fish and is limited by the minimum size of the fish that can be vaccinated (Midtlyng 1997a). In addition, the vaccine has also been linked to a variety of side effects, including impaired growth (Durbin et al. 1999, Melingen \& Wergeland 2002), inflammation and formation of granulomatous lesions (Midtlyng 1997b, 2014, Durbin et al. 1999, Koppang et al. 2005) and fibrous adhesions in the internal organs (Koppang et al. 2005, Berg et al. 2007, Coscelli et al. 2015). Scarification and pigment deposition also occasionally occur (Midtlyng 2014). These side effects have been attributed to the interactions of both the antigens and the oil-emulsion adjuvant, as injection with the adjuvant alone failed to replicate them (Melingen \& Wergeland 2002). Similarly, Romstad et al. (2013) demonstrated a dose-dependent relationship between the concentration of the antigen in the vaccine solution and the development of adhesion. Interestingly, Berg et al. (2007) reported that these side effects were more marked if the fish were vaccinated younger or kept in water at a higher temperature, although Aunsmo et al. (2008) reported that neither weight at vaccination nor sex correlated with the adhesion score in vaccinated fish. Vaccination of the fish through immersion in a vaccinal solution or by oral delivery have both been attempted, but conflicting information exists regarding the degree of protection these methods offer, and the protection has been found to be comparatively short lived (Midtlyng 1997a, 2014). There is therefore a need for the development of new vaccines (Cipriano \& Austin 2011).

Recombinant vaccines have also been investigated. Vaccination using iron-regulated outer membrane proteins and inactivated L-forms has been successfully introduced against A. salmonicida (McIntosh \& Austin 1993, Durbin et al. 1999, Robertson et al. 2005). Outer membrane pore-forming proteins from A. salmonicida were similarly found to provide protective immunity in rainbow trout Oncorhynchus mykiss (Lutwyche et al. 1995). The benefit of polyvalent vaccines has resulted in several products for the control of furunculosis (Austin \& Austin 2012).

Recently, low-frequency ultrasound was found to be efficacious as an adjuvant and to facilitate the uptake of $A$. salmonicida antigens by immersion vaccination (Cobo et al. 2014, Cobo Labarca et al. 2015). While the protection levels conferred by this method still remain to be demonstrated, it constitutes a prom- 
ising new approach for the management of this disease.

The effectiveness of the classical bacterin vaccine in non-salmonid species is still unclear, especially as these other species often harbour different sub-species of the bacterium (Ingilæ et al. 2000, Björnsdóttir et al. 2005). However, Santos et al. (2005) reported being more successful after application of an oral booster. It is worth mentioning that acquired immunity is less efficient at lower temperature, and vaccines might be less protective when applied to species with a lower thermal optimum (Le Morvan et al. 1998). One reason for this variability might be the Alayer; A-layer-deficient isolates are not as efficient when used as vaccines (Arnesen et al. 2010). Conversely, re-attaching the A-layer proteins to a compatible isolate restored protectiveness (Arnesen et al. 2010). Furthermore, when comparing the A-layer protein of various isolates, Lund et al. (2003) found a correlation between the sequence of the A-layer protein and the serological profile. Furthermore, the protective effect of these isolates, when used as a vaccine in spotted wolffish, were higher for other isolates with similar A-layer proteins (Lund et al. 2003). However, those authors showed that vaccines with the A-layer alone only elicited limited protection, demonstrating that this antigen was not the only factor determining the degree of protection of a vaccine solution (Lund et al. 2008). Midtlyng (2014) suggested that truly efficacious vaccines might need to be developed specifically for each fish species.

\section{Selection for disease resistance}

The possibility of breeding fish strains resistant to A. salmonicida infections has also received consideration. For example, an increased bactericidal activity has been described in the sera of rainbow trout selectively bred for their resistance to $A$. salmonicida (Hollebecq et al. 1995). Similarly, Zhang et al. (2011) reported that the sera of resistant salmon families displayed a higher bactericidal activity, linked to the complement activity, against $A$. salmonicida.

Similarly, it has been reported that in Atlantic salmon Salmo salar, low mortality rates $(<35 \%)$ following a challenge with $A$. salmonicida were associated with the presence of specific major histocompatibility complex (MHC) II B alleles (Langefors et al. 2001), suggesting the existence of defined inheritable genetic aspects to disease resistance. The work by Kjøglum et al. (2008b) and Olesen et al. (2007) also showed a high heritability for resistance to the dis- ease. The same was demonstrated in brook charr (Perry et al. 2004)

Several programs have been introduced aimed at taking advantage of this inheritability and producing A. salmonicida-resistant fish. For example, in Norway, breeding programs have aimed at increasing the resistance of the fish to both $A$. salmonicida and infectious salmon anaemia (Ødegård et al. 2007, Kjøglum et al. 2008b). Similarly, in the USA, the Owhi and Rome strains Salvelinus fontinalis have been bred and selected using a cocktail of bacterial isolates and now display a significantly reduced sensitivity to the bacterium (Cipriano et al. 2002).

A concern with the breeding of resistance is the possibility to unwillingly select for detrimental aspects. In particular, it has been suggested that the MHC pattern associated with increased resistance against $A$. salmonicida might be correlated with an increased susceptibility to infectious salmon anaemia (Kjøglum et al. 2008b), although other studies have suggested that the genetic correlation between the resistance against infectious salmon anemia and $A$. salmonicida infections were in fact beneficial, if limited (Kjøglum et al. 2008b).

In carp, differences were observed in the susceptibility of 2 strains to infections by A. salmonicida (Houghton et al. 1991). In turbot, testing of several families revealed the presence of quantitative trait loci that appeared correlated to survival following infection by A. salmonicida (Rodríguez-Ramilo et al. 2011).

\section{Antibiotherapy and antibiotic resistance}

When outbreaks do occur, therapy is still mostly reliant on the distribution of antibiotics, giving rise to concerns about the development of resistance. For example, after surveying multiple Danish farms, Schmidt et al. (2001) reported that $69 \%$ of the isolates sampled were resistant to oxytetracycline; $43 \%$ were resistant to sulphadiazine/trimethoprim, and $20 \%$ were resistant to oxolinic acid, with almost half of these isolates being resistant to a combination of these antibiotics. Widespread resistance to oxytetracycline was also reported from Turkish isolates (Kirkan et al. 2003). Similarly, Ortega et al. (2006) reported that $41.9 \%$ of the 31 A. salmonicida isolates tested were resistant to at least 1 antibiotic. Akinbowale et al. (2006) surveyed multiple isolates originating from aquaculture settings by the agar diffusion (Kirby-Bauer) method. While the authors only identified the various isolates to the genus level, they reported that all 22 tested members 
Table 1. Description of plasmids commonly isolated from Aeromonas salmonicida with special consideration of the antibiotic resistance they carry; from Dallaire-Dufresne et al. (2014; their Table 1). T3SS: type 3 secretion system

\begin{tabular}{|c|c|c|c|c|c|}
\hline $\begin{array}{l}\text { Plasmid } \\
\text { (alternative name) }\end{array}$ & $\begin{array}{l}\text { Length } \\
(\mathrm{kb})\end{array}$ & $\begin{array}{l}\text { Antibiotic } \\
\text { resistance }\end{array}$ & $\begin{array}{l}\text { Special } \\
\text { features }\end{array}$ & Reference & $\begin{array}{c}\text { NCBI accession } \\
\text { number }\end{array}$ \\
\hline pAsa1 (pASal2) & 5.4 & & Cryptic plasmid & Boyd et al. (2003) & NC_004923 \\
\hline pAsa2 (pASal3) & 5.2 & & Cryptic plasmid & Boyd et al. (2003) & NC_004925 \\
\hline pAsa3 & 5.6 & & Cryptic plasmid & Boyd et al. (2003) & NC_004924 \\
\hline pASal1 & 6.5 & & AopP & Boyd et al. (2003) & NC_004338 \\
\hline pASal1B & 9.0 & & AopP & Trudel et al. (2013) & KC686700 \\
\hline pRAS3.1 & 11.8 & Tetracycline & & L'Abée-Lund \& Sørum (2002) & NC_003123 \\
\hline pRAS3.2 & 11.8 & Tetracycline & & L'Abée-Lund \& Sørum (2002) & NC_003124 \\
\hline pAsa6 & 18.5 & & AopH & Najimi et al. (2009) & NC_009352 \\
\hline pASOT3 & 39 & Oxytetracycline & & Adams et al. (1998) & \\
\hline pAr-32 & 44 & $\begin{array}{l}\text { Chloramphenicol, } \\
\text { streptomycin and } \\
\text { sulphonamide }\end{array}$ & & Sørum et al. (2003) & AJ517791 \\
\hline pARS1 & 45 & $\begin{array}{l}\text { Sulphonamide, } \\
\text { tetracycline and } \\
\text { trimethroprim }\end{array}$ & & Sandaa \& Enger (1994) & AJ517790 \\
\hline pASOT & 47 & Oxytetracycline & & Adams et al. (1998) & \\
\hline pASOT2 & 47 & Oxytetracycline & & Adams et al. (1998) & \\
\hline pAsa5 & 155 & & $\begin{array}{c}\text { Majority of the T3SS } \\
\text { apparatus }\end{array}$ & Stuber et al. (2003) & NC_009350 \\
\hline pAsa4 & 167 & $\begin{array}{l}\text { Chloramphenicol, } \\
\text { spectinomycin, strepto- } \\
\text { mycin, sulphonamide } \\
\text { and tetracycline }\end{array}$ & $\begin{array}{c}\text { Resistance to } \\
\text { mercury and } \\
\text { quaternary ammonium } \\
\text { compound }\end{array}$ & Reith et al. (2008) & NC_009349 \\
\hline
\end{tabular}

of the Aeromonas genus were resistant to at least 1 antibiotic, with resistance to ampicillin and amoxicillin being particular common, as $86 \%$ of the isolates were resistant (Akinbowale et al. 2006). Resistance to florfenicol has also been reported (McIntosh et al. 2008), as has resistance to quinolone (Alcaide et al. 2010). Naviner et al. (2011) showed that flumequine treatment increased the prevalence of quinolone-resistant isolates in the intestines of rainbow trout.

Antibiotic resistance genes are mostly carried on mobile genetic elements, and several plasmids have been shown to carry antibiotic resistance genes in isolates of A. salmonicida (Table 1). These genes and plasmids often exist in several related variants (Vincent et al. 2014). For example, pRAS 3.2 and pRA1 both carry tetracycline-resistance determinants, homologous to ones identified in human pathogens (Furushita et al. 2003). Particularly noteworthy is paS4, which carries multiple genes involved in the resistance against several antibiotics, including sulphonamides and anti-microbial compounds (Reith et al. 2008). This has led to concerns regarding the risk of transfer of these resistance phenotypes. For example, L'Abée-Lund \& Sørum (2000) found that the
pRAS2 plasmid, carrying gene for the resistance against sulphonamides, tetracycline and streptomycin could be transferred to Escherichia coli. The same authors also showed that the antibiotic resistance plasmid pRAS 3.1 could be passed onto E. coli, albeit only in the presence of the other plasmids pRAS2 or pRAS1 (L'Abée-Lund \& Sørum 2002). McIntosh et al. (2008) reported resistance plasmids from $A$. salmonicida subsp. salmonicida to the human pathogens E. coli, Edwardsiella tarda and A. hydrophila by conjugation, and Rhodes et al. (2000), comparing aeromonads isolated from both hospitals and fish farms, argued that the 2 environments should be considered linked.

It is important to mention that these studies did not assess the actual directionality of the gene flow. Resistant isolates originating in humans and land animals will more readily contaminate aquatic environments than the reverse, in accordance with the findings of McIntosh et al. (2008). Nonetheless, such transfer from fish to humans is still possible, as suggested with the finding of quinolone-resistant $A$. salmonicida in filets of rainbow trout destined for consumption following treatment with quinolone (Naviner et al. 2011) 


\section{Alternative control methods, including immuno- stimulants, pro- and prebiotics}

Due to the concerns around antibiotic resistance, interest in using various supplements as a means of controlling infections has increased in recent years. The most popular among these might be probiotics: Carnobacterium sp. was found to be antagonistic to both $A$. hydrophila and A. salmonicida (Robertson et al. 2000). Similarly, Balcázar et al. (2008) showed that isolates of Lactobacillus plantarum and L. fermentum inhibited adhesion of several fish pathogens, including A. hydrophila and A. salmonicida. Lactococcus lactis and Leuconostoc mesenteroides similarly improved the survival of rainbow trout to infection with A. salmonicida (Balcázar et al. 2009).

Sica et al. (2012) also studied the properties of lactic acid bacteria and confirmed their efficacy against A. salmonicida. Despite these promising results, our understanding of probiotics is still quite limited: only a small number of studies have been able to demonstrate the mechanism of action of the probiotic treatment (Atlas 1999, Sahu et al. 2008). For example, Garcés et al. (2015) recently investigated the effect of the marine Lactobacillus pentosus H16 against Vibrio alginolyticus and A. salmonicida. They found that the probiotic strain not only had antimicrobial activity against both pathogens but was also able to replace these pathogens, illustrating the mechanism of competitive inhibition (Irianto \& Austin 2002). This was enhanced by the production of a surfactant that reduced the ability of the 2 pathogens to bind to the mucus of their hosts (Garcés et al. 2015). In addition, application of quorumsensing inhibitors or of micro-algae known to interfere with quorum sensing were also protective (Natrah et al. 2012). Despite these isolated examples, our understanding of the mechanisms of action of probiotics are still limited. Furthermore, benefits of probiotics have been variable, and some results have been difficult to replicate (Atlas 1999). It is also unknown how well the benefits of probiotics would translate to a large-scale intensive production. Furthermore, there have been concerns about the probiotics acting as opportunistic pathogens in stressed fish or that the use of probiotics is incompatible with the use of external disinfection in the fish ponds (Sahu et al. 2008). In this context, it appears that more research is needed before the reliability and cost-effectiveness of probiotics have been demonstrated to the point that these treatments get widely adopted by the industry (Gatesoupe 1999, Sahu et al. 2008).
Other tested substances included the immunostimulants glucan or chitosan that were injected into brook trout and found to reduce mortalities during subsequent infections (Anderson \& Siwicki 1994). Similarly, the immunoactive peptide heptanoyl-yD-glutamyl-(L)-mesodiaminopimelyl-(D)-alanine (FK565) was found to improve non-specific immunity and increase the survival rate when subjected to intra-peritoneal infection with $A$. salmonicida (Kitao \& Yoshida 1986). Oral administration of a mixture of heat-inactivated Lactobacillus paracasei, Pichia membranifaciens and Saccharomyces cereviciae has also been shown to increase the expression of several immune genes and to be protective against infection with atypical $A$. salmonicida in cyprinids (Kodama et al. 2011). However, as for probiotics, confirmatory findings have been scarce.

Moreover, phytogenic compounds, i.e. beneficial plant extracts, have also been used to improve the performance of aquaculture (Direkbusarakom 2011). A nanoemulsion of neem Azadirachta indica was found to be inhibitory to A. salmonicida in vitro, and non-pathogenic to walking catfish (Thomas et al. 2013). On the other hand, a screening of 36 plant extracts from Turkey suggested that $A$. salmonicida was resistant to every tested extract (Turker \& Ylldirım 2015).

We recently applied a mix of essential oils, including carvacrol, thymol, anethol, and limonene, and found that its supplementation in the feed allowed halving mortalities, from 37 to $18 \%$, following challenge of rainbow trout with $A$. salmonicida (Menanteau-Ledouble et al. 2015). Similarly, several phytogenic compounds, including extracts from cinnamon, lemongrass, thyme and oregano are inhibitory in vitro against $A$. salmonicida subsp. salmonicida by Starliper et al. (2015).

Several bacteriophages are known to infect $A$. salmonicida, and their use to control infections in aquaculture has received some consideration (Nakai \& Park 2002) but produced mixed results. For example, Verner-Jeffreys et al. (2007) reported that, while addition of bacteriophages delayed the onset of mortality, it had no significant effect on the mortality rate at the end of the challenge, possibly because the bacteria acquired resistance to the virus.

On the other hand, Kim et al. (2012) identified 2 bacteriophages that demonstrated lytic activity against $A$. salmonicida. The first one, a myovirid phage termed phiAS5, was active against a relatively broad range of $A$. salmonicida, and even among other more distantly related aeromonads (Kim et al. 2012), while the second one, PAS-1, was found to reduce 
mortalities during challenge with $A$. salmonicida (Kim et al. 2015). Imbeault et al. (2006) addressed the issue of resistance against bacteriophages with several encouraging results: it was possible to co-infect bacteria with 2 distinct bacteriophages, which signifies that the bacterium has to acquire resistance against both viruses rather than a single bacteriophage. Furthermore, bacteriophage-resistant bacteria displayed a slower growth rate, presumably reducing their virulence. Interestingly, phage resistance was often transient, and more than $25 \%$ of the bacteria lost their resistance at first plating (Imbeault et al. 2006).

Finally, Jung et al. (2016) recently showed that red clay, also known as yellow loess, added to water aggregates with bacterial cells and facilitates their precipitation; it also damages the cellular membrane and causes oxidative stress to the bacteria.

All of these approaches are tantalizing hints toward new possible avenues for treatment; however, they also constitute isolated results that have seldom been replicated. Much research is still needed to confirm the reliability and efficacy of these treatments and to elucidate their mechanisms of action before they can be considered valid alternatives.

\section{CONCLUSION}

Aeromonas salmonicida is a globally distributed pathogen that has historically been among the most important bacteria affecting aquaculture. Currently, vaccines are available that are mostly efficient at keeping the disease under control. Nonetheless, as aquaculture is developed for new species for which this vaccine might be less efficient, new control strategies will be needed, especially considering that the only therapeutic solutions in common usage rely on the use of antibiotics, with all of their associated problems. Alternative solutions are being investigated, the most promising of which might be the application of probiotics and phage therapy. Nonetheless, there is still a strong need for basic research regarding this pathogen as well as its virulence factors and how they interact with the immune system of fish.

Acknowledgements. This work was funded by the Austrian Science Fund (FWF), project no. P 23850-B17.

\section{LITERATURE CITED}

Adams CA, Austin B, Meaden PG, McIntosh D (1998) Molecular characterization of plasmid-mediated oxytetracycline resistance in Aeromonas salmonicida. Appl Environ Microbiol 64:4194-4201
Akinbowale OL, Peng H, Barton MD (2006) Antimicrobial resistance in bacteria isolated from aquaculture sources in Australia. J Appl Microbiol 100:1103-1113

Akyar I, Can S (2013) Rapid identification of Aeromonas species in stool samples with chromogenic media and matrix-assisted laser desorption ionization-time of flight mass spectrometry: an institutional experience. Turk J Med Sci 43:388-392

> Alcaide E, Blasco MD, Esteve C (2010) Mechanisms of quinolone resistance in Aeromonas species isolated from humans, water and eels. Res Microbiol 161:40-45

- Anderson DP, Siwicki AK (1994) Duration of protection against Aeromonas salmonicida in brook trout immunostimulated with glucan or chitosan by injection or immersion. Prog Fish-Cult 56:258-261

Anwar MA, Choi S (2014) Gram-negative marine bacteria: structural features of lipopolysaccharides and their relevance for economically important diseases. Mar Drugs 12:2485-2514

Archuleta TL, Du Y, English CA, Lory S and others (2011) The Chlamydia effector chlamydial outer protein $\mathrm{N}$ (CopN) sequesters tubulin and prevents microtubule assembly. J Biol Chem 286:33992-33998

Arnesen KR, Mikkelsen H, Schrøder MB, Lund V (2010) Impact of reattaching various Aeromonas salmonicida A-layer proteins on vaccine efficacy in Atlantic cod (Gadus morhua). Vaccine 28:4703-4708

Atlas RM (1999) Probiotics-snake oil for the new millennium? Environ Microbiol 1:377-382

> Aunsmo A, Larssen RB, Valle PS, Sandberg M and others (2008) Improved field trial methodology for quantifying vaccination side-effects in farmed Atlantic salmon ( $\mathrm{Sal}$ mo salar L.). Aquaculture 284:19-24

Austin B, Austin DA (2012) Bacterial fish pathogens: diseases of farmed and wild fish, $5^{\text {th }}$ edn. Springer, Chichester

- Austin B, Austin DA, Dalsgaard I, Gudmundsdóttir BK and others (1998) Characterization of atypical Aeromonas salmonicida by different methods. Syst Appl Microbiol 21:50-64

> Balcázar JL, Vendrell D, de Blas I, Ruiz-Zarzuela I, Muzquiz JL, Girones O (2008) Characterization of probiotic properties of lactic acid bacteria isolated from intestinal microbiota of fish. Aquaculture 278:188-191

Balcázar JL, Vendrell D, de Blas I, Ruiz-Zarzuela I, Múzquiz JL (2009) Effect of Lactococcus lactis CLFP 100 and Leuconostoc mesenteroides CLFP 196 on Aeromonas salmonicida infection in brown trout (Salmo trutta). J Mol Microbiol Biotechnol 17:153-157

Barnes AC, Horne MT, Ellis AE (1996) Effect of iron on expression of superoxide dismutase by Aeromonas salmonicida and associated resistance to superoxide anion. FEMS Microbiol Lett 142:19-26

Beaz-Hidalgo R, Figueras MJ (2012) Molecular detection and characterization of furunculosis and other Aeromonas fish infections. In: Carvalho E (ed) Health and environment in aquaculture. InTech, Rijeka, p 97-133

Beaz-Hidalgo R, Figueras MJ (2013) Aeromonas spp. whole genomes and virulence factors implicated in fish disease. J Fish Dis 36:371-388

> Beaz-Hidalgo R, López-Romalde S, Toranzo AE, Romalde JL (2008) Polymerase chain reaction amplification of repetitive intergenic consensus and repetitive extragenic palindromic sequences for molecular typing of Pseudomonas anguilliseptica and Aeromonas salmonicida. J Aquat Anim Health 20:75-85 
Benagli C, Demarta A, Caminada A, Ziegler D, Petrini O, Tonolla M (2012) A rapid MALDI-TOF MS identification database at genospecies level for clinical and environmental Aeromonas strains. PLoS ONE 7:e48441

> Berg A, Rødseth OM, Hansen T (2007) Fish size at vaccination influence [sic] the development of side-effects in Atlantic salmon (Salmo salar). Aquaculture 265:9-15

Bernoth EM (1997) Diagnosis of furunculosis: the tools. In: Bernoth EM, Ellis AE, Midtlyng PJ, Olivier G, Smith P (eds) Furunculosis: multidisciplinary fish disease research. Academic Press, San Diego, CA, p 98-158

Björnsdóttir B, Gudmundsdóttir S, Bambir SH, Gudmundsdóttir BK (2005) Experimental infection of turbot, Scophthalmus maximus (L.), by Aeromonas salmonicida subsp. achromogenes and evaluation of cross protection induced by a furunculosis vaccine. J Fish Dis 28:181-188

Boyd J, Williams J, Curtis B, Kozera C, Singh R, Reith M (2003) Three small, cryptic plasmids from Aeromonas salmonicida subsp. salmonicida A449. Plasmid 50:131-144

> Bricknell IR, Bowden TJ, Bruno DW, MacLachlan P, Johnstone R, Ellis AE (1999) Susceptibility of Atlantic halibut, Hippoglossus hippoglossus (L.) to infection with typical and atypical Aeromonas salmonicida. Aquaculture 175: $1-13$

> Burr SE, Wahli T, Segner H, Pugovkin D, Frey J (2003) Association of Type III secretion genes with virulence of Aeromonas salmonicida subsp. salmonicida. Dis Aquat Org 57:167-171

Burr SE, Pugovkin D, Wahli T, Segner H, Frey J (2005) Attenuated virulence of an Aeromonas salmonicida subsp. salmonicida type III secretion mutant in a rainbow trout model. Microbiology 151:2111-2118

> Chakraborty S, Chaudhuri D, Balakrishnan A, Chakravortty D (2014) Salmonella methylglyoxal detoxification by STM3117-encoded lactoylglutathione lyase affects virulence in coordination with Salmonella pathogenicity island 2 and phagosomal acidification. Microbiology 160: 1999-2017

Cipriano RC, Austin B (2011) Furunculosis and other aeromonad diseases. In: Woo PT, Bruno DW (eds) Fish diseases and disorders, Vol 3. Viral, bacterial and fungal infections, $2^{\text {nd }}$ edn. CABI, Wallingford, p 424-483

Cipriano RC, Bullock GL (2001) Furunculosis and other diseases caused by Aeromonas salmonicida. Fish Disease Leaflet 66. US Department of the Interior, Fish and Wildlife Service, Washington, DC

> Cipriano RC, Marchant D, Jones TE, Schachte JH (2002) Practical application of disease resistance: a brook trout fishery selected for resistance to furunculosis. Aquaculture 206:1-17

> Cobo C, Makosch K, Jung R, Kohlmann K, Knopf K (2014) Enhanced Aeromonas salmonicida bacterin uptake and side effects caused by low frequency sonophoresis in rainbow trout (Oncorhynchus mykiss). Fish Shellfish Immunol 36:444-452

> Cobo Labarca C, Makhutu M, Lumsdon AE, Thompson KD, Jung R, Kloas W, Knopf K (2015) The adjuvant effect of low frequency ultrasound when applied with an inactivated Aeromonas salmonicida vaccine to rainbow trout (Oncorhynchus mykiss). Vaccine 33:1369-1374

> Collins RO, Ferguson DA, Bonniwell MA (1991) Furunculosis in wrasse. Vet Rec 128:43

> Cornick JW, Morrison CM, Zwicker B, Shum G (1984) Atypical Aeromonas salmonicida infection in Atlantic cod, Gadus morhua L. J Fish Dis 7:495-499
Coscelli GA, Bermúdez R, Losada AP, Faílde LD, Santos Y, Quiroga MI (2014a) Acute Aeromonas salmonicida infection in turbot (Scophthalmus maximus L.). Histopathological and immunohistochemical studies. Aquaculture 430:79-85

Coscelli GA, Bermúdez R, Sancho Silva AR, Ruíz de Ocenda MV, Quiroga MI (2014b) Granulomatous dermatitis in turbot (Scophthalmus maximus L.) associated with natural Aeromonas salmonicida subsp. salmonicida infection. Aquaculture 428-429:111-116

Coscelli GA, Bermúdez R, Losada AP, Santos Y, Quiroga MI (2015) Vaccination against Aeromonas salmonicida in turbot (Scophthalmus maximus L.): study of the efficacy, morphological changes and antigen distribution. Aquaculture 445:22-32

> Dacanay A, Knickle L, Solanky KS, Boyd JM and others (2006) Contribution of the type III secretion system (TTSS) to virulence of Aeromonas salmonicida subsp. salmonicida. Microbiology 152:1847-1856

- Dallaire-Dufresne S, Tanaka KH, Trudel MV, Lafaille A, Charette SJ (2014) Virulence, genomic features, and plasticity of Aeromonas salmonicida subsp. salmonicida, the causative agent of fish furunculosis. Vet Microbiol 169:1-7

> Diamanka A, Loch TP, Cipriano R, Faisal M (2013) Polyphasic characterization of Aeromonas salmonicida isolates recovered from salmonid and non-salmonid fish. J Fish Dis 36:949-963

Diamanka A, Loch TP, Cipriano RC, Winters AD, Faisal M (2014) Infection of sea lamprey with an unusual strain of Aeromonas salmonicida. J Wildl Dis 50:159-170

Direkbusarakom S (2011) Application of medicinal herbs to aquaculture in Asia. Walailak J Sci Technol 1:7-14

Durbin M, Mcintosh D, Smith PD, Wardle R, Austin B (1999) Immunization against furunculosis in rainbow trout with iron-regulated outer membrane protein vaccines: relative efficacy of immersion, oral, and injection delivery. J Aquat Anim Health 11:68-75

Faisal M, Eissa AE, Elsayed EE (2007) Isolation of Aeromonas salmonicida from sea lamprey (Petromyzon marinus) with furuncle-like lesions in Lake Ontario. J Wildl Dis 43:618-622

- Falk-Petersen IB, Hansen TK, Fieler R, Sunde LM (1999) Cultivation of the spotted wolffish Anarhichas minor (Olafsen) - a new candidate for cold-water fish farming. Aquacult Res 30:711-718

Farto R, Milton DL, Bermúdez MB, Nieto TP (2011) Colonization of turbot tissues by virulent and avirulent Aeromonas salmonicida subsp. salmonicida strains during infection. Dis Aquat Org 95:167-173

Fast MD, Tse B, Boyd JM, Johnson SC (2009) Mutations in the Aeromonas salmonicida subsp. salmonicida type III secretion system affect Atlantic salmon leucocyte activation and downstream immune responses. Fish Shellfish Immunol 27:721-728

Fehr D, Casanova C, Liverman A, Blazkova H and others (2006) AopP, a type III effector protein of Aeromonas salmonicida, inhibits the NF- $\mathrm{B}$ signalling pathway. Microbiology 152:2809-2818

$>$ Foss A, Imsland AK, Falk-Petersen IB, Øiestad V (2004) A review of the culture potential of spotted wolffish Anarhichas minor Olafsen. Rev Fish Biol Fish 14: 277-294

Furushita M, Shiba T, Maeda T, Yahata M and others (2003) Similarity of tetracycline resistance genes isolated from 
fish farm bacteria to those from clinical isolates. Appl Environ Microbiol 69:5336-5342

> Garcés ME, Sequeiros C, Olivera NL (2015) Marine Lactobacillus pentosus $\mathrm{H} 16$ protects Artemia franciscana from Vibrio alginolyticus pathogenic effects. Dis Aquat Org 113:41-50

Garduño RA, Moore AR, Olivier G, Lizama AL, Garduño E, Kay WW (2000) Host cell invasion and intracellular residence by Aeromonas salmonicida: role of the S-layer. Can J Microbiol 46:660-668

Gatesoupe FJ (1999) The use of probiotics in aquaculture. Aquaculture 180:147-165

> Groves E, Rittinger K, Amstutz M, Berry S, Holden DW, Cornelis GR, Caron E (2010) Sequestering of Rac by the Yersinia effector YopO blocks $\mathrm{Fc} \gamma$ receptor-mediated phagocytosis. J Biol Chem 285:4087-4098

Gudmundsdóttir BK (1996) Comparison of extracellular proteases produced by Aeromonas salmonicida strains, isolated from various fish species. J Appl Microbiol 80: 105-113

Gudmundsdóttir BK (1998) Infections by atypical strains of the bacterium Aeromonas salmonicida. Buvisindi 12: 61-72

Gudmundsdóttir BK, Hvanndal Í, Björnsdóttir B, Wagner U (2003) Analysis of exotoxins produced by atypical isolates of Aeromonas salmonicida, by enzymatic and serological methods. J Fish Dis 26:15-29

Gulla S, Duodu S, Nilsen A, Fossen I, Colquhoun DJ (2015a) Aeromonas salmonicida infection levels in pre- and poststocked cleaner fish assessed by culture and an amended qPCR assay. J Fish Dis 39:867-877

Gulla S, Krossøy B, Vågnes Ø, Colquhoun DJ (2015b) Specific subtypes of atypical Aeromonas salmonicida represent a significant risk to 'cleaner fish' used in Norwegian salmon farming. In: 17th International Conference on Diseases of Fish and Shellfish. European Association of Fish Pathologists, Las Palmas de Gran Canaria, p 99

> Han HJ, Kim DY, Kim WS, Kim CS, Jung SJ, Oh MJ, Kim DH (2011) Atypical Aeromonas salmonicida infection in the black rockfish, Sebastes schlegeli Hilgendorf, in Korea. J Fish Dis 34:47-55

> Hänninen ML, Hirvelä-Koski V (1997) Molecular and phenotypic methods for the characterization of atypical Aeromonas salmonicida. Vet Microbiol 56:147-158

Hellberg H, Moksness E, Hoie S (1996) Infection with atypical Aeromonas salmonicida in farmed common wolffish, Anarhichas lupus L. J Fish Dis 19:329-332

Hiney M, Olivier G (1999) Furunculosis (Aeromonas salmonicida). In: Woo PTK, Bruno DW (eds) Fish diseases and disorders, 1st edn. CAB International Publishing, Wallingford, $\mathrm{p}$ 341-425

Hirvelä-Koski V, Koski P, Niiranen H (1994) Biochemical properties and drug resistance of Aeromonas salmonicida in Finland. Dis Aquat Org 20:191-196

Hjeltnes B, Bergh Ø, Wergeland H, Holm JC (1995) Susceptibility of Atlantic cod Gadus morhua, halibut Hippoglossus hippoglossus and wrasse (Labridae) to Aeromonas salmonicida subsp. salmonicida and the possibility of transmission of furunculosis from farmed salmon Salmo salar to marine fish. Dis Aquat Org 23:25-31

- Hollebecq MG, Faivre B, Bourmaud C, Michel C (1995) Spontaneous bactericidal and complement activities in serum of rainbow trout (Oncorhynchus mykiss) genetically selected for resistance or susceptibility to furunculosis. Fish Shellfish Immunol 5:407-426
Houghton G, Wiergetjes GF, Groeneveld A, Van Muiswinkel WB (1991) Differences in resistance of carp, Cyprinus carpio L., to atypical Aeromonas salmonicida. J Fish Dis 14:333-341

Imbeault S, Parent S, Lagacé M, Uhland CF, Blais JF (2006) Using bacteriophages to prevent furunculosis caused by Aeromonas salmonicida in farmed brook trout. J Aquat Anim Health 18:203-214

Ingilæ M, Arnesen JA, Lund V, Eggset G (2000) Vaccination of Atlantic halibut Hippoglossus hippoglossus L., and spotted wolffish Anarhichas minor L., against atypical Aeromonas salmonicida. Aquaculture 183:31-44

Irianto A, Austin B (2002) Probiotics in aquaculture. J Fish Dis 25:633-642

Jansson E, Eriksson E, Säker E, Dalsgaard I, Nonnemann B, Roozenburg I, Haenen O (2015) Matrix-assisted laser desorption/ionization time of flight, MALDI-TOF, mass spectrometry for identification of fish pathogenic bacteria. In: 17th International Conference on Diseases of Fish and Shellfish. European Association of Fish Pathologists, Las Palmas de Gran Canaria, p 384

> Jeney Z, Jeney G (1995) Recent achievements in studies on diseases of common carp (Cyprinus carpio L.). Aquaculture 129:397-420

> Jones RM, Luo L, Moberg KH (2012) Aeromonas salmonicida-secreted protein AopP is a potent inducer of apoptosis in a mammalian and a Drosophila model. Cell Microbiol 14:274-285

Jung J, Jee SC, Sung JS, Park W (2016) High concentration of red clay as an alternative for antibiotics in aquaculture. J Microbiol Biotechnol 26:130-138

Keeling SE, Brosnahan CL, Johnston C, Wallis R, Gudkovs N, McDonald WL (2013) Development and validation of a real-time PCR assay for the detection of Aeromonas salmonicida. J Fish Dis 36:495-503

Kim JH, Son JS, Choi YJ, Choresca CH and others (2012) Complete genome sequence and characterization of a broad-host range T4-like bacteriophage phiAS5 infecting Aeromonas salmonicida subsp. salmonicida. Vet Microbiol 157:164-171

> Kim JH, Choresca CH, Shin SP, Han JE, Jun JW, Park SC (2015) Biological control of Aeromonas salmonicida subsp. salmonicida infection in rainbow trout (Oncorhynchus mykiss) using Aeromonas phage PAS-1. Transbound Emerg Dis 62:81-86

Kirkan , Göksoy EÖ, Kaya O (2003) Isolation and antimicrobial susceptibility of Aeromonas salmonicida in rainbow trout (Oncorhynchus mykiss) in Turkey hatchery farms. J Vet Med Ser B 50:339-342

> Kitao T, Yoshida Y (1986) Effect of an immunopotentiator on Aeromonas salmonicida infection in rainbow trout (Salmo gairdneri). Vet Immunol Immunopathol 12: 287-296

Kjøglum S, Henryon M, Aasmundstad T, Korsgaard I (2008a) Selective breeding can increase resistance of Atlantic salmon to furunculosis, infectious salmon anaemia and infectious pancreatic necrosis. Aquacult Res 39: 498-505

Kjøglum S, Larsen S, Bakke HG, Grimholt U (2008b) The effect of specific MHC Class I and Class II combinations on resistance to furunculosis in Atlantic salmon (Salmo salar). Scand J Immunol 67:160-168

Kodama H, Nakamura H, Kashima M, Iwasaki T, Togase H (2011) Protection against atypical Aeromonas salmonicida infection in common carp, Cyprinus carpio L., by 
oral administration of a mixed microbial culture of Lactobacillus paracasei, Pichia membranifaciens and Saccharomyces cereviciae. J Vet Med Sci 73:1319-1325

Koppang EO, Haugarvoll E, Hordvik I, Aune L, Poppe TT (2005) Vaccine-associated granulomatous inflammation and melanin accumulation in Atlantic salmon, Salmo salar L., white muscle. J Fish Dis 28:13-22

- Korithoski B, Lévesque CM, Cvitkovitch DG (2007) Involvement of the detoxifying enzyme lactoylglutathione lyase in Streptococcus mutans aciduricity. J Bacteriol 189: 7586-7592

> L'Abée-Lund TM, Sørum H (2000) Functional Tn5393-like transposon in the R plasmid pRAS2 from the fish pathogen Aeromonas salmonicida subspecies salmonicida isolated in Norway. Appl Environ Microbiol 66:5533-5535

L'Abée-Lund TM, Sørum H (2002) A global non-conjugative tet C plasmid, pRAS3, from Aeromonas salmonicida. Plasmid 47:172-181

Lago EP, Nieto TP, Farto R (2012) Virulence factors of Aeromonas salmonicida subsp. salmonicida strains associated with infections in turbot Psetta maxima. Dis Aquat Org 99:145-151

> Lamy B, Kodjo A, Laurent F, ColBVH Study Group (2011) Identification of Aeromonas isolates by matrix-assisted laser desorption ionization time-of-flight mass spectrometry. Diagn Microbiol Infect Dis 71:1-5

> Langefors $\AA$, Lohm J, Grahn M, Andersen Ø, von Schantz T (2001) Association between major histocompatibility complex class IIB alleles and resistance to Aeromonas salmonicida in Atlantic salmon. Proc R Soc Lond B Biol Sci 268:479-485

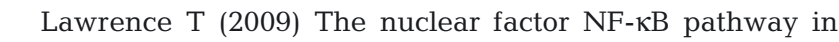
inflammation. Cold Spring Harb Perspect Biol 1:a001651

> Le Morvan C, Troutaud D, Deschaux P (1998) Differential effects of temperature on specific and nonspecific immune defences in fish. J Exp Biol 201:165-168

Lee KK, Ellis AE (1991) Susceptibility of salmonid erythrocytes to lysis by bacterial lipopolysaccharides. J Fish Dis 14:461-465

> Li Y, Hugenholtz J, Abee T, Molenaar D (2003) Glutathione protects Lactococcus lactis against oxidative stress. Appl Environ Microbiol 69:5739-5745

> Livesley MA, Smith SN, Armstrong RA, Barker GA (1999) Characterisation of Aeromonas strains and species by pulsed field gel electrophoresis and principal components analysis. J Fish Dis 22:369-375

Long M, Zhao J, Li T, Tafalla C and others (2015) Transcriptomic and proteomic analyses of splenic immune mechanisms of rainbow trout (Oncorhynchus mykiss) infected by Aeromonas salmonicida subsp. salmonicida. J Proteomics 122:41-54

Lund V, Jenssen LM, Wesmajervi MS (2002) Assessment of genetic variability and relatedness among atypical Aeromonas salmonicida from marine fishes, using AFLPfingerprinting. Dis Aquat Org 50:119-126

> Lund V, Espelid S, Mikkelsen H (2003) Vaccine efficacy in spotted wolffish Anarhichas minor: relationship to molecular variation in A-layer protein of atypical Aeromonas salmonicida. Dis Aquat Org 56:31-42

> Lund V, Arnesen JA, Mikkelsen H, Gravningen K, Brown L, Schrøder MB (2008) Atypical furunculosis vaccines for Atlantic cod (Gadus morhua); vaccine efficacy and antibody responses. Vaccine 26:6791-6799

- Lutwyche P, Exner MM, Hancock REW, Trust TJ (1995) A conserved Aeromonas salmonicida porin provides pro- tective immunity to rainbow trout. Infect Immun 63: 3137-3142

- Magnadóttir B, Gudmundsdóttir BK (1992) A comparison of total and specific immunoglobulin levels in healthy Atlantic salmon (Salmo salar L.) and in salmon naturally infected with Aeromonas salmonicida subsp. achromogenes. Vet Immunol Immunopathol 32:179-189

> Magnadóttir B, Bambir SH, Gudmundsdóttir BK, Pilström L, Helgason S (2002) Atypical Aeromonas salmonicida infection in naturally and experimentally infected cod, Gadus morhua L. J Fish Dis 25:583-597

> Martínez-Murcia AJ, Benlloch S, Collins MD (1992) Phylogenetic interrelationships of members of the genera Aeromonas and Plesiomonas as determined by 16 s ribosomal DNA sequencing: lack of congruence with results of DNA-DNA hybridizations. Int J Syst Bacteriol 42: $412-421$

- Martínez-Murcia AJ, Soler L, Saavedra MJ, Chacon MR, Guarro J, Stackebrandt E, Figueras MJ (2005) Phenotypic, genotypic, and phylogenetic discrepancies to differentiate Aeromonas salmonicida from Aeromonas bestiarum. Int Microbiol 8:259-269

McIntosh D, Austin B (1993) Potential use of vaccines based on cell-wall-defective or deficient (L-form) Aeromonas salmonicida for the control of furunculosis. J Aquat Anim Health 5:254-258

> McIntosh D, Cunningham M, Ji B, Fekete FA and others (2008) Transferable, multiple antibiotic and mercury resistance in Atlantic Canadian isolates of Aeromonas salmonicida subsp. salmonicida is associated with carriage of an IncA/C plasmid similar to the Salmonella enterica plasmid pSN254. J Antimicrob Chemother 61: 1221-1228

- Melingen GO, Wergeland HI (2002) Physiological effects of an oil-adjuvanted vaccine on out-of-season Atlantic salmon (Salmo salar L.) smolt. Aquaculture 214:397-409

Menanteau-Ledouble S, El-Matbouli M (2015) Antigens of Aeromonas salmonicida subsp. salmonicida specifically induced in vivo in Oncorhynchus mykiss. J Fish Dis (in press), doi:10.1111/jfd.12430

Menanteau-Ledouble S, Kattlun J, Nöbauer K, El-Matbouli M (2014a) Protein expression and transcription profiles of three strains of Aeromonas salmonicida ssp. salmonicida under normal and iron-limited culture conditions. Proteome Sci 12:29

> Menanteau-Ledouble S, Soliman H, Kumar G, El-Matbouli $M(2014 b)$ Use of in vivo induced antigen technology to identify genes from Aeromonas salmonicida subsp. salmonicida that are specifically expressed during infection of the rainbow trout Oncorhynchus mykiss. BMC Vet Res 10:298

Menanteau-Ledouble S, Krauss I, Santos G, Fibi S, Weber B, El-Matbouli M (2015) Effect of a phytogenic feed additive on the susceptibility of Onchorhynchus [sic] mykiss to Aeromonas salmonicida. Dis Aquat Org 115:57-66

- Merino S, de Mendoza E, Canals R, Tomás J (2015) Functional genomics of the Aeromonas salmonicida lipopolysaccharide O-antigen and A-layer from typical and atypical strains. Mar Drugs 13:3791-3808

Midtlyng PJ (1997a) Vaccination against furunculosis. In: Bernoth EM, Ellis AE, Midtlyng PJ, Olivier G, Smith P (eds) Furunculosis: multidisciplinary fish disease research. Academic Press, San Diego, CA, p 382-404

Midtlyng PJ (1997b) Vaccinated fish welfare: protection versus side-effects. Dev Biol Stand 90:371-379 
Midtlyng PJ (2014) Vaccination against furunculosis. In: Gudding R, Atle Lillehaug A, Evensen Ø (eds) Fish vaccination. John Wiley \& Sons, Chichester, p 185-199

Miyata M, Aoki T, Inglis V, Yoshida T, Endo M (1995) RAPD analysis of Aeromonas salmonicida and Aeromonas hydrophila. J Appl Bacteriol 79:181-185

Mulder IE, Wadsworth S, Secombes CJ (2007) Cytokine expression in the intestine of rainbow trout (Oncorhynchus mykiss) during infection with Aeromonas salmonicida. Fish Shellfish Immunol 23:747-759

Nagamatsu K, Kuwae A, Konaka T, Nagai S and others (2009) Bordetella evades the host immune system by inducing IL-10 through a type III effector, BopN. J Exp Med 206:3073-3088

> Najimi M, Balado M, Lemos ML, Osorio CR (2009) Genetic characterization of pAsa6, a new plasmid from Aeromonas salmonicida subsp. salmonicida that encodes a type III effector protein AopH homolog. Plasmid 61: 176-181

> Nakai T, Park SC (2002) Bacteriophage therapy of infectious diseases in aquaculture. Res Microbiol 153:13-18

> Nash JHE, Findlay WA, Luebbert CC, Mykytczuk OL and others (2006) Comparative genomics profiling of clinical isolates of Aeromonas salmonicida using DNA microarrays. BMC Genomics 7:43

- Natrah FMI, Alam MI, Pawar S, Harzevili AS and others (2012) The impact of quorum sensing on the virulence of Aeromonas hydrophila and Aeromonas salmonicida towards burbot (Lota lota L.) larvae. Vet Microbiol 159:77-82

> Naviner M, Gordon L, Giraud E, Denis M, Mangion C, Le Bris H, Ganière JP (2011) Antimicrobial resistance of Aeromonas spp. isolated from the growth pond to the commercial product in a rainbow trout farm following a flumequine treatment. Aquaculture 315:236-241

> Nejedlik L, Pierfelice T, Geiser JR (2004) Actin distribution is disrupted upon expression of Yersinia YopO/YpkA in yeast. Yeast 21:759-768

$>$ Nese L, Enger Ø (1993) Isolation of Aeromonas salmonicida from salmon lice Lepeophtheirus salmonis and marine plankton. Dis Aquat Org 16:79-81

> Nielsen B, Olsen JE, Larsen JL (1993) Plasmid profiling as an epidemiological marker within Aeromonas salmonicida. Dis Aquat Org 15:129-135

Nielsen B, Olsen JE, Larsen JL (1994) Ribotyping of Aeromonas salmonicida subsp. salmonicida. Dis Aquat Org 18:155-158

Noga EJ, Berkhoff HA (1990) Pathological and microbiological features of Aeromonas salmonicida infection in the American eel (Anguilla rostrata). Fish Pathol 25:127-132

Novak CW (2013) The salmon louse Lepeophtheirus salmonis (Caligidae) as a vector of Aeromonas salmonicida. MSc thesis, University of British Columbia, Vancouver

O'hIci B, Olivier G, Powell R (2000) Genetic diversity of the fish pathogen Aeromonas salmonicida demonstrated by random amplified polymorphic DNA and pulsed-field gel electrophoresis analyses. Dis Aquat Org 39:109-119

Ødegård J, Olesen I, Gjerde B, Klemetsdal G (2007) Positive genetic correlation between resistance to bacterial (furunculosis) and viral (infectious salmon anaemia) diseases in farmed Atlantic salmon (Salmo salar). Aquaculture 271:173-177

Olesen I, Hung D, Ødegård J (2007) Genetic analysis of survival in challenge tests of furunculosis and ISA in Atlantic salmon. Genetic parameter estimates and model comparisons. Aquaculture 272:S297-S298
Ortega C, Gimeno O, Blanc V, Cortes P, Ania S, Llagostera M (2006) Antibiotic susceptibility of strains of Aeromonas salmonicida isolated from spanish [sic] salmonids. Rev Méd Vét 157:410-414

$>$ Pavan ME, Abbott SL, Zorzopulos J, Janda JM (2000) Aeromonas salmonicida subsp. pectinolytica subsp. nov., a new pectinase-positive subspecies isolated from a heavily polluted river. Int J Syst Evol Microbiol 50: 1119-1124

> Perry GM, Tarte P, Croisetière S, Belhumeur P, Bernatchez L (2004) Genetic variance and covariance for $0+$ brook charr (Salvelinus fontinalis) weight and survival time of furunculosis (Aeromonas salmonicida) exposure. Aquaculture 235:263-271

> Rasch M, Kastbjerg VG, Bruhn JB, Dalsgaard I, Givskov M, Gram L (2007) Quorum sensing signals are produced by Aeromonas salmonicida and quorum sensing inhibitors can reduce production of a potential virulence factor. Dis Aquat Org 78:105-113

Rattanachaikunsopon P, Phumkhachorn P (2012) Detection of Aeromonas salmonicida by reverse transcription-multiplex polymerase chain reaction. Biosci Biotechnol Biochem 76:665-670

Reith M, Singh R, Curtis B, Boyd J and others (2008) The genome of Aeromonas salmonicida subsp. salmonicida A449: insights into the evolution of a fish pathogen. BMC Genomics 9:427

> Rhodes G, Huys G, Swings J, McGann P, Hiney M, Smith P, Pickup RW (2000) Distribution of oxytetracycline resistance plasmids between aeromonads in hospital and aquaculture environments: implication of Tn1721 in dissemination of the tetracycline resistance determinant tet A. Appl Environ Microbiol 66:3883-3890

Roberts RJ (2012) The bacteriology of teleosts. In: Roberts RJ (ed) Fish pathology, $4^{\text {th }}$ edn. Wiley-Blackwell, Oxford, p 339-382

> Robertson PAW, O'Dowd C, Burrells C, Williams P, Austin B (2000) Use of Carnobacterium sp. as a probiotic for Atlantic salmon (Salmo salar L.) and rainbow trout (Oncorhynchus mykiss, Walbaum). Aquaculture 185: 235-243

Robertson PAW, Austin DA, Austin B (2005) Prevention of ulcer disease in goldfish by means of vaccination. J Aquat Anim Health 17:203-209

Rodger HD, Dreczkowski G, Gibson D (1997) The successful control of atypical Aeromonas salmonicida infection in captive common wolfish, Anarhichas lupus. Bull Eur Assoc Fish Pathol 17:158-160

Rodríguez-Ramilo ST, Toro MA, Bouza C, Hermida M and others (2011) QTL detection for Aeromonas salmonicida resistance related traits in turbot (Scophthalmus maximus). BMC Genomics 12:541

Rojas V, Camus-Guerra H, Guzmán F, Mercado L (2015) Pro-inflammatory caspase-1 activation during the immune response in cells from rainbow trout Oncorhynchus mykiss (Walbaum 1792) challenged with pathogen-associated molecular patterns. J Fish Dis 38: 993-1003

Romstad AB, Reitan LJ, Midtlyng P, Gravningen K, Evensen $\varnothing$ (2013) Antibody responses correlate with antigen dose and in vivo protection for oil-adjuvanted, experimental furunculosis (Aeromonas salmonicida subsp. salmonicida) vaccines in Atlantic salmon (Salmo salar L.) and can be used for batch potency testing of vaccines. Vaccine 31:791-796 
Rønneseth A, Haugland GT, Brudal E, Wergeland HL (2015) Bacterial diseases and vaccination of farmed lumpfish (Cyclopterus lumpus L.). In: 17th International Conference on Diseases of Fish and Shellfish. European Association of Fish Pathologists, Las Palmas de Gran Canaria, p 97

Sahu MK, Swarnakumar NS, Sivakumar K, Thangaradjou T, Kannan L (2008) Probiotics in aquaculture: importance and future perspectives. Indian J Microbiol 48:299-308

Saleh M, Soliman H, Haenen O, El-Matbouli M (2011) Antibody-coated gold nanoparticles immunoassay for direct detection of Aeromonas salmonicida in fish tissues. J Fish Dis 34:845-852

Samuelsen OB, Nerland AH, Jørgensen T, Schrøder MB, Svåsand T, Bergh Ø (2006) Viral and bacterial diseases of Atlantic cod Gadus morhua, their prophylaxis and treatment: a review. Dis Aquat Org 71:239-254

Sandaa RA, Enger Ø (1994) Transfer in marine sediments of the naturally occurring plasmid pRAS1 encoding multiple antibiotic resistance. Appl Environ Microbiol 60: 4234-4238

Santos Y, García-Marquez S, Pereira PG, Pazos F and others (2005) Efficacy of furunculosis vaccines in turbot, Scophthalmus maximus (L.): evaluation of immersion, oral and injection delivery. J Fish Dis 28:165-172

Schmidt AS, Bruun MS, Dalsgaard I, Larsen JL (2001) Incidence, distribution, and spread of tetracycline resistance determinants and integron-associated antibiotic resistance genes among motile aeromonads from a fish farming environment. Appl Environ Microbiol 67:5675-5682

Schromm AB, Brandenburg K, Loppnow H, Moran AP, Koch MHJ, Rietschel ET, Seydel U (2000) Biological activities of lipopolysaccharides are determined by the shape of their lipid A portion. Eur J Biochem 267:2008-2013

Schwenteit J, Gram L, Nielsen KF, Fridjonsson OH, Bornscheuer UT, Givskov M, Gudmunsdóttir BK (2011) Quorum sensing in Aeromonas salmonicida subsp. achromogenes and the effect of the autoinducer synthase AsaI on bacterial virulence. Vet Microbiol 147:389-397

Sha J, Galindo CL, Pancholi V, Popov VL, Zhao Y, Houston CW, Chopra AK (2003) Differential expression of the enolase gene under in vivo versus in vitro growth conditions of Aeromonas hydrophila. Microb Pathog 34: 195-204

Shotts EB, Talkington FD, Elliott DG, McCarthy DH (1980) Aetiology of an ulcerative disease in goldfish Carassius auratus (L.): characterization of the infectious agent. J Fish Dis 3:181-186

Sica MG, Brugnoni LI, Marucci PL, Cubitto MA (2012) Characterization of probiotic properties of lactic acid bacteria isolated from an estuarine environment for application in rainbow trout (Oncorhynchus mykiss, Walbaum) farming. Antonie Leeuwenhoek 101:869-879

Sørum H, L'Abée-Lund TM, Solberg A, Wold A (2003) Integron-containing IncU R plasmids pRAS1 and pAr-32 from the fish pathogen Aeromonas salmonicida. Antimicrob Agents Chemother 47:1285-1290

Starliper CE, Ketola HG, Noyes AD, Schill WB, Henson FG, Chalupnicki MA, Dittman DE (2015) An investigation of the bactericidal activity of selected essential oils to Aeromonas spp. J Adv Res 6:89-97

Stuber K, Burr SE, Braun M, Wahli T, Frey J (2003) Type III secretion genes in Aeromonas salmonicida subsp. salmonicida are located on a large thermolabile virulence plasmid. J Clin Microbiol 41:3854-3856
Swift S, Karlyshev AV, Fish L, Durant EL and others (1997) Quorum sensing in Aeromonas hydrophila and Aeromonas salmonicida: identification of the LuxRI homologs AhyRI and AsaRI and their cognate N-acylhomoserine lactone signal molecules. J Bacteriol 179:5271-5281

Thomas J, Jerobin J, Seelan TSJ, Thanigaivel S, Vijayakumar S, Mukherjee A, Chandrasekaran N (2013) Studies on pathogenecity of Aeromonas salmonicida in catfish Clarias batrachus and control measures by neem nanoemulsion. Aquaculture 396-399:71-75

Treasurer JW (2012) Diseases of north European wrasse (Labridae) and possible interactions with cohabited farmed salmon, Salmo salar L. J Fish Dis 35:555-562

Treasurer JW, Birkbeck TH, Laidler LA, Cox DI (2007) Atypical Aeromonas salmonicida infection in naturally- and laboratory-challenged farmed haddock, Melanogrammus aeglefinus (L.). J Fish Dis 30:313-318

Trudel MV, Tanaka KH, Filion G, Daher RK, Frenette M, Charette SJ (2013) Insertion sequence AS5 (IS AS5) is involved in the genomic plasticity of Aeromonas salmonicida. Mob Genet Elements 3:e25640

Turker H, Yıldırım AB (2015) Screening for antibacterial activity of some Turkish plants against fish pathogens: a possible alternative in the treatment of bacterial infections. Biotechnol Biotechnol Equip 29:281-288

Vågnes $\varnothing$, Biering E, Almås K (2014) Development of injection and cohabitation challenge models for atypical Aeromonas salmonicida in farmed ballan wrasse (Labrus bergylta). Veterinærinstituttets Rapportserie 1-2014. Norwegian Veterinary Institute, Oslo

Vanden Bergh P, Frey J (2014) Aeromonas salmonicida subsp. salmonicida in the light of its type-three secretion system. Microb Biotechnol 7:381-400

Vanden Bergh P, Heller M, Braga-Lagache S, Frey J (2013) The Aeromonas salmonicida subsp. salmonicida exoproteome: global analysis, moonlighting proteins and putative antigens for vaccination against furunculosis. Proteome Sci 11:44

Verner-Jeffreys DW, Algoet M, Pond MJ, Virdee HK, Bagwell NJ, Roberts EG (2007) Furunculosis in Atlantic salmon (Salmo salar L.) is not readily controllable by bacteriophage therapy. Aquaculture 270:475-484

> Villumsen KR, Koppang EO, Raida MK (2015) Adverse and long-term protective effects following oil-adjuvanted vaccination against Aeromonas salmonicida in rainbow trout. Fish Shellfish Immunol 42:193-203

- Vincent AT, Trudel MV, Paquet VE, Boyle B and others (2014) Detection of variants of the pRAS3, pAB5S9, and pSN254 plasmids in Aeromonas salmonicida subsp. salmonicida: multidrug resistance, interspecies exchanges, and plasmid reshaping. Antimicrob Agents Chemother 58:7367-7374

> Wang Z, Li J, Altman E (2006) Structural characterization of the lipid A region of Aeromonas salmonicida subsp. salmonicida lipopolysaccharide. Carbohydr Res 341: 2816-2825

> Wang Z, Liu X, Dacanay A, Harrison BA and others (2007) Carbohydrate analysis and serological classification of typical and atypical isolates of Aeromonas salmonicida: a rationale for the lipopolysaccharide-based classification of A. salmonicida. Fish Shellfish Immunol 23: 1095-1106

Whittington RJ, Djordjevic SP, Carson J, Callinan RB (1995) Restriction endonuclease analysis of atypical Aeromonas salmonicida isolates from goldfish Carassius auratus, sil- 
ver perch Bidyanus bidyanus, and greenback flounder Rhombosolea tapirina in Australia. Dis Aquat Org 22: 185-191

Wiklund T, Dalsgaard I (1998) Occurrence and significance of atypical Aeromonas salmonicida in non-salmonid and salmonid fish species: a review. Dis Aquat Org 32:49-69

Woolery AR, Yu X, LaBaer J, Orth K (2014) AMPylation of

Editorial responsibility: David Bruno,

Aberdeen, UK
Rho GTPases subverts multiple host signaling processes. J Biol Chem 289:32977-32988

Zhang Z, Niu C, Storset A, Bøgwald J, Dalmo RA (2011) Comparison of Aeromonas salmonicida resistant and susceptible salmon families: a high immune response is beneficial for the survival against Aeromonas salmonicida challenge. Fish Shellfish Immunol 31:1-9

Submitted: May 28, 2015; Accepted: April 14, 2016

Proofs received from author(s): May 23, 2016 